\title{
СПОНТАННА ФЛОРА ДЕРЖАВНОГО ДЕНДРОЛОГІЧНОГО ПАРКУ «ОЛЕКСАНДРІЯ» НАН УКРАЇНИ (м. БІЛА ЦЕРКВА, КИЇВСЬКА ОБЛАСТЬ)
}

\author{
Шиндер О. І., Дойко Н. М.
}

\section{ВСТУП}

На сучасному етапі вивчення біорізноманіття відбувається в умовах глобальних кліматичних змін та зростаючого антропічного навантаження, особливо в урбанізованому середовищі. Аборигенний компонент флори перебуває під різностороннім пресингом, внаслідок чого рідкісні й менш стійкі види випадають із рослинного покриву. Натомість зростає рівень синантропізації рослинного покриву, активно відбувається його фітозабруднення чужорідними видами рослин ${ }^{1,2}$. Надзвичайно виражено ці процеси відбуваються в інтродукційних осередках, а саме ботанічних садах і дендропарках, створених на основі природних біотопів. Залишки аборигенних фітоценозів та їх змодельовані аналоги - культурфітоценози - в інтродукційних установах часто є цінними осередками популяцій аборигенних видів і потребують постійного моніторингу. Крім того, в умовах інтенсивної інтродукційної роботи таксономічний склад спонтанного рослинного покриву інтродукційних осередків надзвичайно динамічний, а його вивчення за уніфікованою методикою має велике значення з огляду на загрозу фітоінвазій.

Державний дендрологічний парк «Олександрія» НАН України (м. Біла Церква) є одним із перших осередків інтродукційної роботи в Україні, закладений у 1788 р. На його території (нині площа становить 400,67 га) поєднуються великі фрагменти природної рослинності та різноманітні культурфітоценози (рис. 1). Видовий склад місцевих та чужорідних рослин Парку із середини XIX ст. привертав увагу багатьох поколінь дослідників. Це підкреслює важливість Парку у розвитку вітчизняної флористики, але накопичені за довгий період відомості до останнього часу залишалися переважно фрагментарними. Отже, інвентаризація спонтанного флорорізноманіття на території «Олександрії» була актуальним завданням.

\footnotetext{
${ }^{1}$ Протопопова В.В. Синантропная флора Украины и пути ее развития. Киев : Наукова думка, 1991. 204 с.

2 Протопопова В.В., Шевера М.В. Інвазійні види у флорі України. І. Група високо активних видів. GEO\&BIO. 2019. Vol. 17. P. 116-135. DOI: 10.15407/gb.2019.17.116.
} 


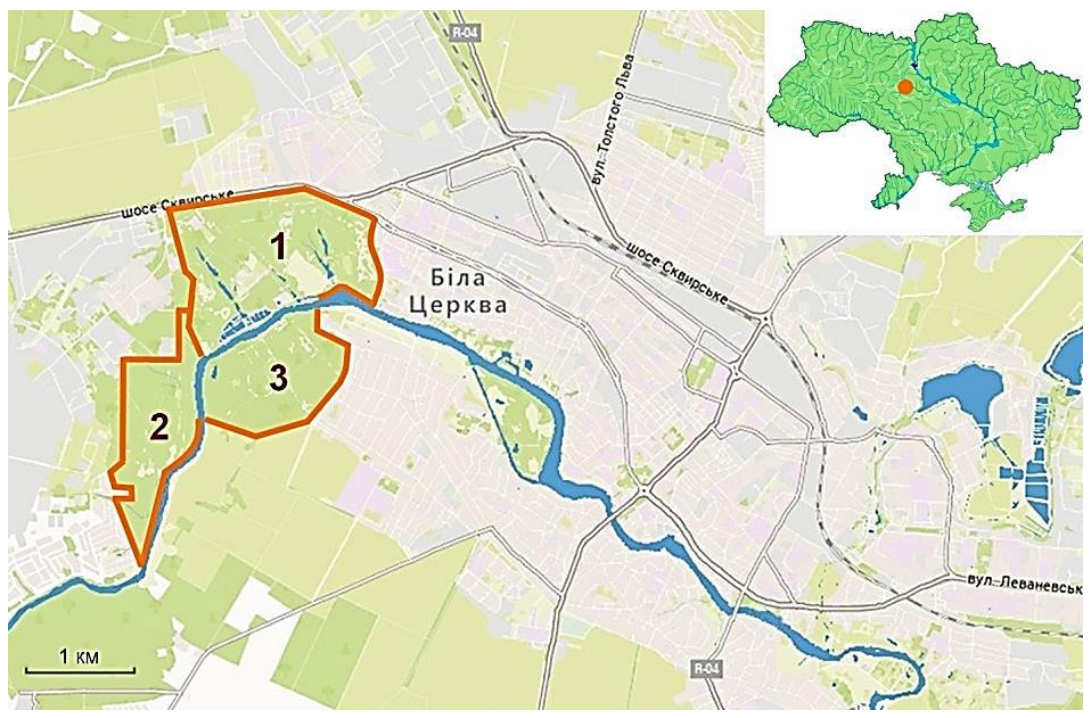

Рис. 1. Географічне розташування дендрологічного парку «Олександрія». 1 - історична частина (201,6 га), 2 - нова територія, урочище Гайок (із 1999 р., 95,5 га), 3 - нова територія, урочище Голендерня (із 2010 р., 103,6 га)

\section{1. Історія дослідження}

Перші відомості про рослинний покрив дендропарку «Олександрія» 3'являються у наукових роботах із середини XIX ст. Ф.И. Базинер у своїй роботі ${ }^{3}$ описав природні умови колишньої Київської губернії і морозостійкість деревних порід, а також повідомив про знахідку двох молодих дерев Acer pseudoplatanus у лісі біля Парку, звідки, очевидно, було занесене насіння. Це одна з перших у вітчизняній літературі вказівок про дичавіння інтродукованих рослин. Також Ф.И. Базинер згадує низку інтродуцентів у Парку, таких як абрикоси, бук і шипшина бенгальська. Пізніше поодинокі флористичні вказівки навели інші автори. Так, А. Рогович зазначив для Парку здичавілу Oxalis stricta ${ }^{4}$, K. Lapczyński повідомив, що Cyclamen europaeum перебуває тут у дикому стані біля десяти років ${ }^{5}$, про здичавіння Asclepias syriaca

3 Базинер Ф.И. О растительности и климате Киевской губернии. Журнал министерства государственных имуществ. 1853. Кн. 2. С. 1-46.

${ }^{4}$ Рогович А. Обозрение сосудистых и полусосудистых растений, входящих в состав флоры губерний Киевской, Черниговской и Полтавской. Киев : Унив. тип., 1855. $147 \mathrm{c}$.

${ }^{5}$ Lapczyński K. Rośliny z okolic Białejcerkwi. Pamiętnik fizyograpiczny. Warszawa, 1889. T. 9. S. 36-54. 
повідомив В. Финк ${ }^{6}$ («целая площадь одичалого ваточника»). Ймовірно, на сучасній території Парку А.Л. Анджейовський виявив Aruncus dioicus ${ }^{7}$.

Цінні відомості, хоча й виключно інтродукційного характеру, навів А.О. Небесский ${ }^{8}$, опублікувавши список акліматизованих деревних i кущових порід у саду графа О. Браницького. Цей перелік засвідчує факт зростання інтродукованих видів у «Олександрії» на кінець ХІХ ст. i має значення для уточнення культигенного та синантропного ареалів багатьох із них. Так, у цьому переліку згадуються види, які нині здичавіли в Парку, зокрема Fraxinus pensylvanica, Ligustrum vulgare, Lonicera ruprechtii, Morus alba.

У XX ст. грунтовні відомості про флору Парку опублікував М.К. Гродзінський ${ }^{9,10}$. Автор навів опис степової рослинності на Палієвій горі, зазначивши, зокрема, зниклі сьогодні види, такі як Jurinea cyanoides, Linum flavum, Stipa pennata, а також зазначив низку адвентивних видів рослин в «Олександрії». Подібні знахідки на території Парку взагалі ставали прикладами появи нових адвентивних видів у флорі України ${ }^{11,12}$. Поодинокі вказівки в цей період траплялися в деяких інших працях ${ }^{13,14}$.

У середині ХХ ст. вийшла багатотомна «Флора УРСР» ${ }^{15}$, у якій наведено кільканадцять вказівок про зростання на території Парку місцевих та адвентивних рослин. Надзвичайно цінними є праці, в яких

${ }^{6}$ Финк В. Список некоторых растений, пригодных для культуры на неудобной земле. Записки Имп. общ. с.-х. Юж. России. 1890. № 12. С. 1-17.

7 Рогович А. Обозрение семенных и высших споровых растений, входящих в состав флоры губерний Киевского учебного округа: Волынской, Подольской, Киевской, Черниговской и Полтавской. Киев : Унив. тип., 1869. 308 с.

8 Небесский А.О. Список древесных и кустарниковых пород растений, акклиматизованных в саду графа А. Браницкого близ Киева. Труды отдела ботаники Императорского общества акклиматизации животных и растений. 1899. № 1. С. 122-132.

9 Гродзінський М.К. Білоцерківщина. Рослинність Білоцерківщини. Труди Білочерківського Краєзнавчого Товариства. 1928. Т. 1. Вип. 4. С. 1-79.

10 Гродзінський М.К. Матеріали до флори Білоцерківщини. Записки Білочерківського с.-г. політехнікуму. 1929. Т. 1. Вип. 1. С. 9-22.

${ }^{11}$ Оксіюк П.В. До питання про поширення адвентивних рослин на Україні. Наукові записки. Орган Київських науково-дослідчих катедр. 1924. Т. 2. С. 121-129.

${ }^{12}$ Котов М.І. Адвентивна рослинність на Україні. Вісник природознавства. 1928. № 5-6. С. 267-274.

13 Зеров Д.К. До флори Черкаської округи (кол. Черкаський та Чигиринський повіти) Київщини. Вісник Київського ботанічного саду. 1924. Вип. 1. С. 5-26.

${ }_{14}$ Клеопов Ю.Д. Анализ флоры широколиственных лесов европейской части СССР / отв. ред. Д.Н. Доброчаева. Киев : Наукова думка, 1990. 352 с.

15 Флора УРСР : у 12 т. / за ред. О.В. Фоміна, С.І. Бордзіловського, С.М. Лавренка, М.І. Котова та ін. Київ : видавництво АН УРСР, 1936-1965. 
представлені описи окремих ділянок. Детальний опис рослинного покриву багатьох ділянок «Олександрії» та іiі дендрофлори у цей час навів И.Г. Дерий ${ }^{16}$. Г.І. Білик висвітлив склад і структуру лучного степу на Палієвій горі ${ }^{17}$. Дещо пізніше Г.В. Кляшторная ${ }^{18}$ навела повний видовий склад цього ж схилу станом на 1978 р., зазначивши для багатьох видів трапляємість, що дає змогу прослідкувати поетапність зникнення деяких рідкісних степових рослин у цьому урочищі. Ця ж авторка навела детальну фітоценотичну характеристику вікової діброви «Олександрії» 19,20 .

У наступні десятиліття нові відомості щодо флори «Олександрії» були переважно фрагментарні й представлені вказівками окремих злаків ${ }^{21}$ i видів зі складу інших родин ${ }^{22,23,24}$. Н.Н. Цвелев за зразком із Дендропарку описав новий таксон, а саме Geranium sibiricum subsp. popovii ${ }^{25}$, який, втім, нині не визнається самостійним. У новому столітті у низці робіт опубліковано окремі оригінальні та за гербарними матеріалами флористичні вказівки з території Парку ${ }^{26,27}$. В.В. Гриценко

${ }^{16}$ Дерий И.Г. Дендрофлора парка «Александрия» ботанического сада АН УССР. Акклиматизация растений. Киев : изд-во АН УССР, 1958. С. 110-132.

17 Білик Г.І. Лучні степи. Рослинність УРСР. Степи. Кам'янисті відслонення. Піски / за ред. А.І. Барбарича. Київ : Наукова думка, 1973. С. 33-94.

${ }^{18}$ Кляшторная Г.В. Флора южного склона Палиевой горы дендрозаповедника «Александрия» АН УССР - реликт степной растительности Правобережной Лесостепи Украины. Восстановление и обогащение парковых ландшафтов на Украине : сборник научных трудов. Киев: Наукова думка, 1981б. С. 61-69.

${ }^{19}$ Кляшторная Г.В. Папоротник «Страусово перо» - ценное реликтовое и редкое декоративное растение. Восстановление и обогащение парковых ландиафтов на Украине : сборник научных трудов. Киев : Наукова думка, 1981а. С. 99-101.

20 Кляшторная Г.В. Фитоценотическая характеристика травянистой дубравы дендропарка «Александрия» АН УССР. Оптимизаџия структуры парковых насаждений с использованием интродуцентов : сборник научных трудов. Киев : Наукова думка, 1990. С. 27-32.

${ }^{21}$ Прокудин Ю.Н., Вовк А.Г., Петрова О.А. и др. Злаки Украины. Киев : Наукова думка, 1977. 518 с.

22 Доброчаєва Д.М. Шорстколисті (Boraginales Hutch.) європейської частини СРСР : дис. ... докт. біол. наук. Додаток. Київ, 1977. Т. 1. С. 1-305. Т. 2. С. 306-624.

${ }^{23}$ Бортняк М.М. Матеріали до флори Київської області. Украӥнський ботанічний журнал. 1975. Т. 32. № 4. С. 445-448.

${ }^{24}$ Сытник К.М., Андрощук А.Ф., Клоков М.В. и др. Тысячелистники. Киев : Наукова думка, 1984. 272 с.

${ }^{25}$ Цвелев Н.Н. Заметки о гераниевых (Geraniaceae) флоры Восточной Европы. Нов. сист. выси. р. Санкт-Петербург : Наука, 1993. Т. 29. С. 95-99.

${ }_{26}$ Андрик Є.Й., Балог Л., Шевера М.В. Humulus japonicus Siebold. et Zucc. (Cannabaceae) - новий адвентивний вид флори України. Український ботанічний журнал. 2010. Т. 67. № 3. С. 438-443. 
навела нові відомості про стан лучно-степової ділянки на Палієвій горі $^{28}$. В останні десятиліття співробітниками Парку опубліковано каталоги деревних і трав'яних рослин установи ${ }^{29,30}$, а також низку оглядових праць щодо окремих груп рослин ${ }^{31,32,33}$.

Цінні збори колекційної i спонтанної флори «Олександрії» зберігаються у гербарії KW і датовані переважно першою половиною XX ст., a на етикетках найчастіше зустрічаються прізвища Балковського, Гродзинського, Котова, Оксіюка, Шиманського. На жаль, колектори далеко не завжди зазначали, у якому стані зібрані рослини: культурні, місцеві чи здичавілі. Багато зборів із Парку присутні у гербарії KWHA і представлені частіше культурною флорою. Окремі збори зустрічаються в інших гербаріях України та Росії, зокрема LE, KWU. Нині співробітники Парку проводять активну роботу щодо наповнення власного довідкового гербарію «Олександрії».

Отже, фрагментарні відомості про рослинний покрив «Олександрії» містяться у багатьох джерелах і частково були узагальнені у сучасних каталогах та переліках видів різних груп флори Парку. Однак вивчення спонтанної флори Парку як цілісної системи залишається актуальним завданням.

Метою дослідження $є$ проведення інвентаризації таксономічного складу спонтанної флори Державного дендрологічного парку «Олександрія» НАН України, аналіз ії структури, оцінювання сучасної динаміки. Дослідження було проведено впродовж 2017-2020 pp. i базувалось на польових обстеженнях території Парку, камеральному

27 Чорна Г.А. Нові знахідки Carex hordeistichos Vill. та Carex paniculata L. (Суреraceae) в Правобережному Лісостепу України. Украйнський ботанічний журнал. 2004. Т. 61. № 1. С. 62-68.

28 Гриценко В.В. Лучні степи Київського плато: флора, рослинність, популяції рідкісних видів та охорона : дис. ... канд. біол. наук : спец. 03.00.05. Київ, 2007. 358 с.

${ }^{29}$ Бойко Н.С., Дойко Н.М., Драган Н.В. та ін. Каталог дерев'янистих рослин Державного дендрологічного дендропарку «Олександрія» НАН України / за ред. C.I. Галкіна. Біла Церква, 2013. 62 с.

30 Дойко Н.М., Калашнікова Л.В., Рубіс В.Л. Каталог трав'янистих рослин Державного дендрологічного дендропарку «Олександрія» НАН України / за ред. С.І. Галкіна. Біла Церква, 2013. 65 с.

31 Галкін С.I., Дойко Н.М. Адвентивна фракція трав'янистої рослинності дендропарку «Олександрія» НАН України. Інтродукиія рослин. 2012. № 1. С. 94-104.

32 Дойко Н.М., Катревич М.В. Трав'янисті ергазіофігофіти в дендропарку «Олександрія». Інтродукція рослин, збереження та збагачення біорізноманіття в ботанічних садах та дендропарках : матеріали конференції, присвяченій 80-річчю від дня заснування НБС ім. М.М. Гришка (Київ, 15-17 вересня 2015 р.). Київ, 2015. С. 76-77.

33 Левон Ф.М., Драган Н.В., Мордатенко Л.П., Галкін С.І. Природне поновлення хвойних рослин в дендропарку «Олександрія». Біоекологічні аспекти. Інтродукиія $i$ зелене будівництво : збірник наукових праць. Біла Церква : Мустанг, 2000. С. 115-122. 
обробленні результатів і критичному опрацюванні літературних та інших джерел. Номенклатура таксонів у конспекті вивірена за базою даних "Plants of the World Online" з окремими доповненнями.

Весь обсяг флори поділено на такі фракції: аборигенна (місцеві таксони) й адвентивна (чужорідні таксони), а останню додатково - на групу ксенофітів (чужорідні таксони, що увійшли до флори без прямої участі людини) й групу втікачів з культури (здичавілі інтродуценти або ергазіофіти). Методологію розмежування цих груп висвітлено в попередній роботі одного 3 авторів ${ }^{34}$. Для відділення групи видів«втікачів із культури» від інтродуцентів, які не вийшли за межі культури, використали головний принцип: таксон слід зарахувати до адвентивних, якщо виявлено два i більше його спонтанні місцезростання (дорослі особини або повноцінні різновікові популяції) за межами ділянки вирощування i не поруч із нею. В додатковий перелік винесено таксони, які були помилково наведені для території Парку в літературних джерелах як дикорослі. Географічний, біоморфологічний та еколого-ценотичний аналізи проведено за класичними схемами ${ }^{35,36,37}$ з урахуванням особливостей дослідженої флори та досвіду інших подібних робіт ${ }^{38}$.

\section{2. Таксономічне багатство}

Спонтанна флора «Олександрії» первинно була локальною флорою Київського плато, а нині $є$ антропічно трансформованою флорою інтродукційного осередку. За результатами інвентаризації встановлено, що за весь час на території «Олександрії» було достовірно зафіксовано 830 таксонів із 416 родів 92 родин. Аборигенна фракція включає 571 таксон, а адвентивна - 259 таксонів (табл. 1). На території Парку вперше виявлено місцезростання малопоширеного на території нашої країни таксону - Rumex sanguineus, а також ідентифіковано велику кількість інших таксонів, які раніше не наводилися. В ході дослідження для «Олександрії», а також інтродукційних установ м. Києва наведено

34 Шиндер O.I. Спонтанна флора Національного ботанічного саду імені М.М. Гришка НАН України (м. Київ). Повідомлення 2. Методологічні проблеми і критерії виділення ергазіофітів в умовах інтродукційного центру. Інтродукція рослин. 2019а. № 2. C. 3-16. DOI: 10.5281/zenodo.3240995.

${ }^{35}$ Клеопов, 1990.

${ }^{36}$ Протопопова, 1991.

37 Серебряков И.Г. Морфология вегетативных органов высших растений. Москва : Советская наука, 1952. 391 с.

38 Виноградова Ю.К., Майоров С.Р., Бочкин В.Д. Влияние чужеродных видов растений на динамику флоры территории Главного ботанического сада РАН. Российский журнал биологических инвазий. 2015. № 4. С. 22-41. 
нові для адвентивної флори України види, такі як Lonicera $\times$ notha $\mathrm{i}$ L. ruprechtiana ${ }^{39}$.

Нині ймовірно зниклими є принаймні 29 видів рослин, зокрема 17 видів iз аборигенних місцезнаходжень. Серед зниклих місцевих видів переважають рідкісні степові види, багато з яких перебували в околицях Білої Церкви на межі поширення, зокрема Aster bessarabicus, Clematis integrifolia, Gentiana cruciata, Jurinea cyanoides, Linum flavum, L. perenne, Pontechium maculatum, Pulsatilla grandis, Stipa pennata. У віковій діброві зникли Lilium martagon i Neottia nidus-avis. До зниклих, можливо, належать Carex humilis, Dianthus capitatus subsp. andrzejowskianus та низка інших таксонів, які останнім часом не вдалося підтвердити. Отже, актуальний склад флори має на момент дослідження 801 вид. Загальна пропорція спонтанної флори така: $1: 4,5: 9,0$.

Таблиця 1

Вищі таксони флори Державного дендропарку «Олександрія»

\begin{tabular}{|c|c|c|c|c|}
\hline \multirow{2}{*}{ Вищий таксон } & \multicolumn{2}{|c|}{ Аборигенна фракція } & \multicolumn{2}{c|}{ Адвентивна фракція } \\
\cline { 2 - 5 } & $\begin{array}{c}\text { кількість видів } \\
\text { (зокрема, зниклих) }\end{array}$ & $\%$ & $\begin{array}{c}\text { кількість видів } \\
\text { (зокрема, зниклих) }\end{array}$ & $\%$ \\
\hline Equisetophyta & 2 & 0,4 & - & - \\
\hline Polypodiophyta & 6 & 1,1 & - & - \\
\hline Pinophyta & - & - & 3 & 1,2 \\
\hline Magnoliophyta & 563 & 98,5 & 256 & 98,8 \\
\hline зокрема, Liliopsida & $124(-2)$ & 21,7 & 32 & 12,1 \\
\hline Rosopsida & $439(-15)$ & 76,8 & $224(-12)$ & 86,7 \\
\hline Всього & $571(-17)$ & 100 & $259(-12)$ & 100 \\
\hline Головні пропорції & $1: 3,9: 7,5$ & \multicolumn{3}{c}{$1: 3,2: 4,6$} \\
\hline
\end{tabular}

Встановлено, що видове багатство рослинного покриву «Олександрії» $\epsilon$ найбільшим серед інших таких, наведених для інтродукційних осередків України, але загалом вкладається у загальну тенденцію взаємозалежності площі інтродукційної установи і багатства спонтанної флори ${ }^{40}$. Різноманітність флори Парку пояснюється поєднанням кількох факторів. Насамперед завдяки великій території тут збереглися на значній площі ділянки з природними угрупованнями (різної міри збереженості) на берегах р. Рось, а саме лісовими,

${ }^{39}$ Шиндер O.І., Неграш Ю.М., Глухова С.А., Дойко Н.М., Рак О.О. Адвентивні види роду Lonicera (Caprifoliaceae) у флорі Правобережної України. Наукові записки НаУКМА. Біологія $i$ екологія. 2020. Т. 3. С. 58-65. DOI: 10.18523/26174529.2020.3.58-65.

40 Шиндер O.I. Спонтанна флора Національного ботанічного саду імені М.М. Гришка НАН України (м. Київ). Повідомлення 4. Адвентивні види: Ксенофіти. Інтродукція рослин. 2019б. № 4. С. 18-33. DOI: 10.5281/zenodo.3566608. 
степовим, лучними, водними і гранітних відслонень, що сприяє формуванню багатого місцевого флорорізноманіття. 3 іншого боку, тут понад двох століть триває інтродукційна робота, яка сприяла проникненню в природні та антропічно змінені біотопи багатьох чужорідних видів рослин. Для порівняння, сучасна флора НБС імені М.М. Гришка НАНУ (м. Київ, площа становить 129,8 га) (далі - НБС) станом на 2019 р. включала 650 таксонів, а флора НДП «Софіївка» НАНУ (м. Умань, площа становить 179,2 га) станом на 2011 р. 528 видів $^{41}$; для ГБС РАН (м. Москва, Росія, площа становить 331,49 га) наведено 856 видів $^{42}$.

Найбільшою цінністю флори відзначено раритетну компоненту, яка включає 8 видів із Червоної книги України ${ }^{43}$, таких як Adonis vernalis, Galanthus nivalis, Lilium martagon, Neottia nidus-avis, Pulsatilla grandis, P. pratensis, Stipa capillata, S. pennata, та 21 регіонально-рідкісний вид. Хоча частина 3 них уже зниклі, територія Парку продовжує відігравати надзвичайно важливу фітосозологічну роль у справі охорони місцезростань рідкісних рослин. Завданням на майбутнє є науково обгрунтована репатріація зниклих популяцій рідкісних видів на території «Олександрії».

Серед флористичних вказівок для території «Олександрії» зустрічаються такі, що не завжди однозначно належать до дикорослих рослин. Такою $є$ наведена в парку як дикоросла Centaurea stricta (sub C. montana L. var. axillaris Willd.): «між кущами, чимала зарость» ${ }^{44}$ або наведене як природне місцезростання Onoclea struthiopteris ${ }^{45}$. Сюди ж, імовірно, належить вказівка Aruncus dioicus 3 околиць Білої Церкви ${ }^{46}$. Втім, подекуди автори знахідок наголошували на тому, що мова, ймовірно, йдеться саме про рослини в місцях садіння, такі як Hepatica nobilis ${ }^{47}$ i Hosta plantaginea ${ }^{48}$.

Невелику групу складають види, які у флористичних роботах неодноразово наводились для Білої Церкви чи власне «Олександрії» у вигляді острівних локалітетів. Так, за зборами Балковського були наведені місцезнаходження таких видів: Anchusa ochroleuca - для

41 Куземко А.А., Ковтонюк А.І. Таксономічна та екологічна структура спонтанної флори Національного дендрологічного парку «Софіївка» НАН України. Автохтонні та інтродуковані рослини. 2015. Вип. 11. С. 111-120.

${ }^{42}$ Виноградова и др. 2015.

43 Червона книга України. Рослинний світ / за ред. Я.П. Дідуха. Київ : Глобалконсалтинг, 2009. 900 с.

${ }^{44}$ Гродзінський, 1929.

45 Кляшторная, 1981.

${ }^{46}$ Рогович, 1869.

${ }^{47}$ Гродзінський, 1929.

${ }^{48}$ Оксіюк, 1924. 
«Олександрії» як острівне ${ }^{49}$; Hieracium silvularum - для Білої Церкви як єдине в рівнинній Україні ${ }^{50}$; Heliotropium europaeum - для «Олександрії» як єдине в Правобережному Лісостепу ${ }^{51}$; Geranium nepalense - для «Олександрії» як втікач із культури ${ }^{52}$. В цій групі $€$ зразок диз'юнктивно-ареального виду Clinopodium menthifolium: «дендропарк Александрия, судубрава», 14.10.1955, Б. Балковский (sub Nepeta officinalis L.) - Det. 21.03.2018., О. Шиндер (sub Calamintha menthifolia (Host) Merino) (KW)53 ${ }^{53}$. Також B.I. Чопик навів острівний локалітет Erodium beketowii на картосхемі поширення в околиці Білої Церкви ${ }^{54}$. Однак відомості про зростання цих видів у Парку в дикому стані не наведені, отже, припускаємо, що вищенаведені вказівки стосуються культивованих рослин. Таким $є$ західноєвропейський Cytisus scoparius, котрий був наведений для околиць Білої Церкви як адвентивний ${ }^{55}$, але в гербарії KWHА всі три зразки цього виду звідти взяті з культивованих рослин, наприклад: «Белая Церковь, заповедник, уч. бобовые», 16.05.1966, Т.Ф. Коляда, Н.М. Грисюк (KWHA). Тут слід згадати Lysimachia verticillata, яку Ю.Д. Клеопов розглядав на околиці Білої Церкви як приклад диз'юнктивно-ареального виду Середньої Наддніпрянщини ${ }^{56}$. Насправді, ця вказівка стосується здичавілого у Парку близького виду L. punctata.

\section{3. Структура флори}

Аборигенна фракція флори «Олександрії» репрезентує 55,1\% такої флори всього Київського плато, для якої наведено 1036 аборигенних

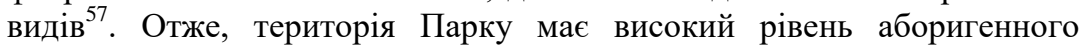
флорорізноманіття та є одним із його осередків на Київському плато.

${ }^{49}$ Флора..., 1957.

50 там же, 1965.

51 там же, 1957.

52 Протопопова В.В. Адвентивні рослини Лісостепу і Степу України. Київ : Наукова думка, 1973. 192 с.

${ }_{53}$ Шиндер O.I. Хорологічні особливості Clinopodium menthifolium (Lamiaceae) i Sedum borissovae (Crassulaceae) - рідкісних видів флори Правобережжя України. Рослинний світ у Червоній книзі Украӥни: впровадження Глобальної стратегії збереження рослин : Матеріали 5 конференції (25-28 червня 2018 р.). Херсон, 2018. C. 93-96.

54 Чопик В.И. Редкие и исчезающие растения Украины : справочник. Київ : Наукова думка, 1978. 216 с.

55 Мельник B.I., Баранський О.Р. Генезис та динаміка ареалу Sarothamnus scoparius (Fabaceae) у межах України. Украӥнський ботанічний журнал. 2017. T. 74. № 4. C. 334-346. DOI: 10.15407/ukrbotj74.04.334.

${ }^{56}$ Клеопов, 1990.

57 Фіцайло Т.В. Структурно-порівняльна оцінка диференціації ценофлор Київського плато : дис. ... канд. біол. наук : спец. 03.00.05. Київ, 2000. 432 с. 
Частка адвентивних видів у дослідженій флорі становить $31,2 \%$, що вдвічі більше, ніж загалом на Київському плато (станом на 2000 р. частка становить $15,2 \%)^{58}$, але менше, ніж наведено у НБС (40,9\%) та інших інтродукційних осередках із антропічно трансформованими територіями. Такий рівень адвентизації для інтродукційного центру, очевидно, слід розцінювати як превалюючий вплив аборигенного різноманіття над адвентивним у формуванні спонтанної флори. Подібний рівень адвентизації відзначено у спонтанній флорі дендрологічного парку «Асканія-Нова» (смт Асканія-Нова), а саме $31,6 \% 59$. Завдяки адвентизації у спонтанну флору Парку проникли види зі 118 родів і 16 родин, не характерних для місцевої флори.

Згідно зі спектром провідних родин (табл. 2), аборигенна флора «Олександрії» належить до Rosaceae-типу, характерного для Середньої та Північної Свропи ${ }^{60}$. Позиції «бореальної» родини Cуреraceae та «аридно-євразійської» Fabaceae врівноважені і мають понижені ранги. Такий родинний спектр досить характерний для флор більш заліснених регіонів Лісостепу. Розподіл провідних родин адвентивної фракції дуже характерний для всієї адвентивної флори України ${ }^{61}$.

Таблиця 2

Провідні родини спонтанної флори Державного дендропарку «Олександрія»

\begin{tabular}{|c|c|c|c|c|c|}
\hline \multicolumn{3}{|c|}{ Аборигенна фракція } & \multicolumn{3}{c|}{ Адвентивна фракція } \\
\hline № & Родина & $\begin{array}{c}\text { Кількість } \\
\text { видів }\end{array}$ & № & Родина & $\begin{array}{c}\text { Кількість } \\
\text { видів }\end{array}$ \\
\hline 1 & Asteraceae & 73 & 1 & Asteraceae & 40 \\
\hline 2 & Poaceae & 54 & 2 & Poaceae & 26 \\
\hline 3 & Rosaceae & 38 & 3 & Brassicaceae & 17 \\
\hline 4 & Lamiaceae & 29 & 4 & Amaranthaceae & 15 \\
\hline 5 & Apiaceae & 27 & 5 & Rosaceae & 12 \\
\hline 6 & Cyperaceae & 26 & 6 & Fabaceae & 11 \\
\hline 7 & Fabaceae & 26 & 7 & Lamiaceae & 10 \\
\hline
\end{tabular}

У складі адвентивної фракції дві головні імміграційні групи розподілені таким чином: ксенофітів - 104 (40,2\%), втікачів із культури

${ }^{58}$ Там же.

59 Гавриленко Н.О., Мойсієнко I.І., Шаповал В.В. Спонтанна флора дендрологічного парку «Асканія-Нова». Вісті Біосферного заповідника «АсканіяНова». 2008. Т. 10. С. 49-73.

60 Хохряков А.П. Таксономические спектры и их роль в сравнительной флористике. Ботанический журнал. 2000. Т. 85. № 5. С. 1-11.

${ }^{61}$ Протопопова, 1973, 1991. 
(разом із кількома ксено-ергазіофітами) - 155 (59,8\%). Переважання втікачів із культури (ергазіофітів за походженням) характерне для флор інтродукційних установ та урбанофлор. Так, у НБС цей показник становить $53,8 \%$, у ГБС $-85,4 \%{ }^{62}$, в урбанофлорі м. Києва $-63,4 \%^{63}$.

За ступенем натуралізації адвентивні види належать до двох компонентів флори, а саме стабільного й нестабільного. Перший об'єднує натуралізовані чужорідні види (агріофіти, епекофіти), і вони разом 3 аборигенними рослинами формують сукупність власне природної флори. Нестабільний елемент флори включає нестійкі види, які в місцях занесення існують лише впродовж одного сезону чи тривалості життя занесених особин без формування наступних генерацій (ефемерофіти) або утворюють локальну популяцію (колонофіти). Крім того, загальнопоширеним є поділ адвентивних видів за часом проникнення їх у флору регіону на археофіти (з'явилися у флорі України до кінця XV ст.) і кенофіти (з'явилися пізніше). Розподіл відповідних груп адвентивних видів наведено у табл. 3. Серед найбільш явних закономірностей слід назвати абсолютне переважання серед ксенофітів стабільного компоненту і значне домінування нестабільного компоненту серед втікачів з культури. Місто Біла Церква знаходиться далеко від первинних осередків поширення неінтродукованих чужорідних видів ${ }^{64}$, причому серед них переважають археофіти. Отже, група ксенофітів у флорі «Олександрії» представлена переважно давно занесеними видами.

Зовсім інший розподіл у групі втікачів із культури, де переважає нестабільний компонент, а частка археофітів дуже мала. Це цілком очікувано для флори інтродукційного осередку, де велика кількість інтродуцентів (ергазіофітів) проходять стадії акліматизації i натуралізації, а 3 часом дичавіють. На території Парку такі види перебувають на різних етапах виходу 3 культури і представлені як спонтанними популяціями, їх локусами або вегетативними клонами, так і розсіяними самосівними особинами. Через подібну картину території інтродукційних осередків часто не беруться до уваги під час вивчення урбанофлор, а фіксуються лише факти появи втікачів 3 культури уже за межами ботанічного саду чи дендропарку. Однак наш досвід вивчення спонтанного рослинного покриву таких установ вказує на те, що процеси натуралізації та експансії інтродуцентів як у межах інтродукційних осередків, так і на інших територіях нічим не різняться.

${ }^{62}$ Шиндер, 20196.

63 Яворська О.Г. Адвентивна фракція синантропної флори Київської міської агломерації : дис. ... канд. .біол. наук : спец. 03.00.05. Київ, 2002. 252 с.

${ }^{64}$ Протопопова, 1973. 
Натомість концентрація на порівняно невеликій площі спонтанних місцезростань багатьох інтродуцентів значно ускладнює їх фіксацію, тому задля цього ми застосували «правило двох спонтанних місцезростань». Для порівняння, в адвентивній флорі Київської агломерації частка стабільного компоненту становить біля $37,6 \%{ }^{65}$.

Таблиця 3

\section{Структура адвентивної фракції флори Державного дендропарку} «Олександрія» за ступенем натуралізації та часом імміграції

\begin{tabular}{|c|c|c|c|c|c|c|}
\hline \multirow{2}{*}{ Категорія } & \multicolumn{2}{|c|}{ Ксенофіти } & \multicolumn{2}{c|}{$\begin{array}{c}\text { Втікачі } \\
\text { з культри }\end{array}$} & \multicolumn{2}{|c|}{ Вся фракція } \\
\cline { 2 - 7 } & $\begin{array}{c}\text { кіль- } \\
\text { кість } \\
\text { видів }\end{array}$ & $\begin{array}{c}\text { частка, } \\
\text { \% }\end{array}$ & $\begin{array}{c}\text { кіль- } \\
\text { кість } \\
\text { видів }\end{array}$ & $\begin{array}{c}\text { частка, } \\
\text { \% }\end{array}$ & $\begin{array}{c}\text { кіль- } \\
\text { кість } \\
\text { видів }\end{array}$ & $\begin{array}{c}\text { частка, } \\
\text { \% }\end{array}$ \\
\hline \multicolumn{7}{|c|}{ За ступенем натуралізації } \\
\hline $\begin{array}{c}\text { стабільний } \\
\text { компонент }\end{array}$ & 101 & 97,1 & 48 & 31,0 & 149 & 57,5 \\
\hline $\begin{array}{c}\text { нестабільний } \\
\text { компонент }\end{array}$ & 3 & 2,9 & 107 & 69,0 & 110 & 42,5 \\
\hline \multicolumn{7}{|c|}{ 3а часом проникнення } \\
\hline археофіти & 66 & 63,5 & 12 & 7,7 & 78 & 30,1 \\
\hline кенофіти & 38 & 36,5 & 143 & 92,3 & 181 & 69,9 \\
\hline Всього & 104 & 100 & 155 & 100 & 259 & 100 \\
\hline
\end{tabular}

В географічній структурі аборигенної фракції серед регіональних типів ареалів простежується найбільший вплив західних елементів: частка неморального i трьох європейських геоелементів становить $31,2 \%$ (табл. 4). Частка південного і східного елементів (лісостеповий, степовий і субсередземноморський геоелементи) значно нижче, а саме $16,5 \%$. Дуже невелику частку має бореальний елемент. Таким чином, географічний спектр свідчить про формування дослідженої флори під найбільшим впливом європейської широколистянолісової зони.

Серед адвентивних видів найбільше мають субсередземноморське походження (табл. 5). Пофракційний аналіз дає змогу уточнити географічну структуру обох різних за походженням імміграційних груп адвентивної фракції. Так, серед ксенофітів частка субсередземноморського елементу становить 57,7\%, що дає всій групі чіткого південного характеру, а у групі втікачів із культури незначно переважають види американського походження, однак частка субсередземноморських та азійських видів також висока. Подібна структура 3 високою часткою зазначених трьох регіонів походження

${ }^{65}$ Яворська, 2002. 
(21,0\%, 26,6\% і 18,9\% відповідно) була нами відзначена серед втікачів iз культури в адвентивній флорі НБС. Такий спектр можна охарактеризувати як мультирегіональний, i він свідчить про різнопланову інтродукційну діяльність установи.

Таблиця 4

Географічна структура аборигенної фракції флори Державного дендропарку «Олександрія»

\begin{tabular}{|c|c|c|}
\hline Геоелемент & $\begin{array}{c}\text { Кількість } \\
\text { видів }\end{array}$ & Частка, \% \\
\hline Палеоарктичний & 201 & 35,2 \\
\hline Голарктичний & 63 & 11,0 \\
\hline Неморальний & 59 & 10,3 \\
\hline Свропейсько-середземноморський & 57 & 10,0 \\
\hline Євразійський степовий & 37 & 6,5 \\
\hline Свропейський & 34 & 6,0 \\
\hline Субсередземноморський & 30 & 5,3 \\
\hline Свразійський лісостеповий & 27 & 4,7 \\
\hline Плюрирегіональний & 20 & 3,5 \\
\hline Середньоєвропейський & 19 & 3,3 \\
\hline Бореальний & 15 & 2,6 \\
\hline Східноєвропейський & 9 & 1,6 \\
\hline Всього & 571 & 100 \\
\hline
\end{tabular}

Таблиця 5

Географічна структура адвентивної фракції флори Державного дендропарку «Олександрія»

\begin{tabular}{|c|c|c|c|c|}
\hline \multirow[b]{2}{*}{ Геоелемент } & \multicolumn{3}{|c|}{ Кількість видів } & \multirow[b]{2}{*}{$\begin{array}{c}\text { Частка, } \\
\%\end{array}$} \\
\hline & $\begin{array}{c}\text { ксено- } \\
\text { фіти }\end{array}$ & $\begin{array}{c}\text { втікачі } \\
3 \text { культури }\end{array}$ & $\begin{array}{c}\text { вся } \\
\text { фракція }\end{array}$ & \\
\hline Американський & 18 & 48 & 66 & 25,5 \\
\hline Євразійський & 2 & 5 & 7 & 2,7 \\
\hline Азійський & 18 & 37 & 55 & 21,2 \\
\hline Субсередземноморський & 60 & 38 & 98 & 37,8 \\
\hline Європейський & 4 & 16 & 20 & 7,7 \\
\hline Палеотропічний & 2 & 1 & 3 & 1,2 \\
\hline Антропічний & - & 10 & 10 & 3,9 \\
\hline Всього & 104 & 155 & 259 & 100 \\
\hline
\end{tabular}

Біоморфологічна структура флори складається відповідно до умов формування флори, це ж стосується ії окремих фракцій, відповідні спектри яких виявляються кардинально відмінними (табл. 6). Розподіл життєвих форм аборигенних видів подібний до такого у флорі Київського плато, 
зокрема у флорі Парку деревних форм $10,5 \%$, а трав'яних $-89,5 \%$, а в регіональній флорі - 9,5\% і 90,5\% відповідно ${ }^{66}$. Отже, флора «Олександрії» має типові лісостепові риси регіональної флори.

\section{Таблиця 6}

Біоморфологічна структура спонтанної флори Державного дендропарку «Олександрія»

\begin{tabular}{|c|c|c|c|c|c|c|c|c|}
\hline \multirow{2}{*}{ Біоморфи } & \multirow{2}{*}{$\begin{array}{c}\text { Аборигенна } \\
\text { фракція }\end{array}$} & \multicolumn{2}{|c|}{ ксенофіти } & \multicolumn{2}{|c|}{$\begin{array}{c}\text { втікачі } \\
\text { культури }\end{array}$} & \multicolumn{2}{|c|}{ вся фракція } \\
\cline { 3 - 9 } & $\begin{array}{c}\text { кіль- } \\
\text { кість } \\
\text { видів }\end{array}$ & $\begin{array}{c}\text { час- } \\
\text { тка, } \\
\text { \% }\end{array}$ & $\begin{array}{c}\text { кіль- } \\
\text { кість } \\
\text { видів }\end{array}$ & $\begin{array}{c}\text { час- } \\
\text { тка, } \\
\text { \% }\end{array}$ & $\begin{array}{c}\text { кіль- } \\
\text { кість } \\
\text { видів }\end{array}$ & $\begin{array}{c}\text { час- } \\
\text { тка, } \\
\text { \% }\end{array}$ & $\begin{array}{c}\text { кіль- } \\
\text { кість } \\
\text { видів }\end{array}$ & $\begin{array}{c}\text { час- } \\
\text { тка, } \\
\text { \% }\end{array}$ \\
\hline Дерева & 27 & 4,7 & - & - & 31 & 20,0 & 31 & 12,0 \\
\hline Кущі & 21 & 3,7 & - & - & 11 & 7,1 & 11 & 4,2 \\
\hline Кущики & 8 & 1,4 & - & - & 2 & 1,3 & 2 & 0,8 \\
\hline Півкущики & 3 & 0,5 & - & - & 2 & 1,3 & 2 & 0,8 \\
\hline Ліани деревні & 1 & 0,2 & - & - & 8 & 5,2 & 8 & 3,1 \\
\hline $\begin{array}{c}\text { Трави } \\
\text { однорічні }\end{array}$ & 63 & 11,0 & 82 & 78,8 & 35 & 22,6 & 117 & 45,2 \\
\hline $\begin{array}{c}\text { Трави } \\
\text { дворічні }\end{array}$ & 36 & 6,3 & 11 & 10,6 & 7 & 4,5 & 18 & 6,9 \\
\hline $\begin{array}{c}\text { Трави } \\
\text { багаторічні }\end{array}$ & 399 & 69,9 & 11 & 10,6 & 59 & 38,1 & 70 & 27,0 \\
\hline Трави водні & 13 & 2,3 & - & - & - & - & - & - \\
\hline Всього & 571 & 100 & 104 & 100 & 155 & 100 & 259 & 100 \\
\hline
\end{tabular}

Група ксенофітів представлена виключно травами, причому переважно однорічними $(78,8 \%)$. Така ж картина відзначена у спонтанній флорі НБС, причому частка однорічників там досягає $91,9 \%{ }^{67}$. Це співвідноситься 3 географічним спектром групи і характерно для всієї адвентивної флори України: поширення великої кількості малорічних чужорідних видів із «південним» характером ${ }^{68}$. У групі втікачів із культури зовсім інший біоморфологічний спектр: участь провідних біоморф досить вирівнена, частка деревних видів становить $34,9 \%$ (і майже збігається з такою у флорі НБС, що становить $34,3 \%$ ), багаторічні трави дещо перевищують це число, а участь малорічників складає 27,1\%. Такий розподіл також подібний серед втікачів із культури у НБС, лише багаторічників там значно більше, а саме 53,8\%, а малорічників - 11,9\%. Загалом це свідчить про те, що серед інтродуцентів схильність до натуралізації i високу

\footnotetext{
${ }^{66}$ Фіцайло, 2000.

${ }^{67}$ Шиндер, 2019б.

${ }^{68}$ Протопопова, 1991.
} 
конкурентоспроможність мають переважно багаторічні біоморфи. Слід відзначити, що у стабільному компоненті серед втікачів із культури у флорі «Олександрії» частка деревних форм досягає 43,4\%, а багаторічних трав - лише $32,1 \%$, отже, серед натуралізованих інтродуцентів саме деревні рослини відзначаються найбільшою різноманітністю і схильністю дичавіти та експансувати.

Еколого-ценотична структура флори Парку безпосередньо відображає його природні умови. Як видно 3 табл. 7, в аборигенній фракції переважають болотні, лучні, лісові, степові та узлісні види, що цілком характерно для лісостепової флори. Порівняно висока частка болотного флорокомплексу пояснюється розташуванням Парку на берегах р. Рось.

Таблиця 7

Еколого-ценотична структура спонтанної флори Державного дендропарку «Олександрія»

\begin{tabular}{|c|c|c|c|c|c|c|c|c|}
\hline \multirow{2}{*}{$\begin{array}{c}\text { Цено- } \\
\text { елемент }\end{array}$} & \multirow{2}{*}{$\begin{array}{c}\text { Аборигенна } \\
\text { фракція }\end{array}$} & \multicolumn{6}{|c|}{ ксенофіти } & \multicolumn{2}{c|}{$\begin{array}{c}\text { втікачі } \\
\text { з культури }\end{array}$} & \multicolumn{2}{|c|}{ вся фракція } \\
\cline { 3 - 9 } & $\begin{array}{c}\text { кіль- } \\
\text { кість } \\
\text { видів }\end{array}$ & $\begin{array}{c}\text { час- } \\
\text { тка, } \\
\text { \% }\end{array}$ & $\begin{array}{c}\text { кіль- } \\
\text { кість } \\
\text { видів }\end{array}$ & $\begin{array}{c}\text { час- } \\
\text { тка, } \\
\text { \% }\end{array}$ & $\begin{array}{c}\text { кіль- } \\
\text { кість } \\
\text { видів }\end{array}$ & $\begin{array}{c}\text { час- } \\
\text { тка, } \\
\text { \% }\end{array}$ & $\begin{array}{c}\text { кіль- } \\
\text { кість } \\
\text { видів }\end{array}$ & $\begin{array}{c}\text { час- } \\
\text { тка, } \\
\text { \% }\end{array}$ \\
\hline Водний & 19 & 3,3 & - & - & 1 & 0,6 & 1 & 0,4 \\
\hline Лісовий & 136 & 23,8 & 3 & 2,9 & 31 & 20,0 & 34 & 13,1 \\
\hline Узлісний & 100 & 17,5 & 1 & 1,0 & 26 & 16,8 & 27 & 10,4 \\
\hline Болотний & 67 & 11,7 & 1 & 1,0 & 4 & 2,6 & 5 & 1,9 \\
\hline Лучний & 106 & 18,6 & 4 & 3,8 & 11 & 7,1 & 15 & 5,8 \\
\hline Степовий & 67 & 11,7 & 1 & 1,0 & 1 & 0,6 & 2 & 0,8 \\
\hline Лесовий & 1 & 0,2 & - & 0,0 & - & - & - & 0,0 \\
\hline Псамофітний & 31 & 5,4 & 2 & 1,9 & 2 & 1,3 & 4 & 1,5 \\
\hline Наскельний & 7 & 1,2 & - & 0,0 & 1 & 0,6 & 1 & 0,4 \\
\hline Синантропний & 37 & 6,5 & 92 & 88,5 & 77 & 49,7 & 169 & 65,3 \\
\hline Альпійський & - & - & - & - & 1 & 0,6 & 1 & 0,4 \\
\hline Всього & 571 & 100 & 104 & 100 & 155 & 100 & 259 & 100 \\
\hline
\end{tabular}

В адвентивній фракції закономірно переважають синантропні види, які часто не закріпилися в нових умовах у певній еколого-ценотичній ніші. Однак серед втікачів із культури досить висока частка лісових та узлісних видів, що сприяє значній участі цієї групи рослин у фітоінвазіях у відповідні рослинні угруповання. Нині в умовах «Олександрії» найбільшою шкодочинністю для зелених насаджень і природних угруповань відзначаються 6 здичавілих інтродуцентів, таких як Acer negundo, Ailanthus altissima, Parthenocissus inserta, Robinia pseudoacacia, Solidago canadensis i Toxicodendron radicans. Вони потребують вжиття постійних заходів зі стримування наслідків 
розповсюдження й боротьби 3 ними. Ще кілька десятків адвентивних видів мають порівняно високі фітоценотичні позиції і потребують моніторингу у зв'язку із загрозами фітоінвазій ${ }^{69}$. Більш детально проблема таких видів буде розглянута в наступних публікаціях.

Загалом, як і щодо спонтанної флори НБС, флора «Олександрії» має високий рівень аборигенного флорорізноманітня і зберегла чимало особливостей місцевої лісостепової флори, крім того, у них досить рівномірно проникли основні групи чужорідних видів, тому ці обидві флори можна розглядати як еталонні спонтанні флори інтродукційних осередків Правобережного Лісостепу.

\section{ВИСНОВКИ}

Таким чином, дендрологічний парк «Олександрія» - це один із перших інтродукційних осередків України, що існує впродовж більш ніж 2 століть, і за довгий період тут сформувалась надзвичайно багата спонтанна флора, яка у своїй основі є локальною флорою Київського плато, до складу якої додався обширний чужорідний елемент. У ii складі зафіксовано 830 таксонів, зокрема 571 аборигенний i 259 чужорідних. В ході дослідження 3'ясувалося, що з різних причин ціла низка видів для флори Парку і Білої Церкви загалом наводилась помилково. Аналіз структури дослідженої флори свідчить про те, що, незважаючи на значну антропічну трансформацію внаслідок паркобудівництва та інтродукційної роботи, у ній збереглися природні риси, а рівень адвентизації $(31,2 \%)$ значно менший від такого в інших інтродукційних осередках. Серед місцевих рослин переважають широкоареальні $(46,2 \%)$, неморальні $(10,3 \%)$ i європейськосубсередземноморські $(10,0 \%)$ види, серед ї життєвих форм багаторічні трави $(69,9 \%)$, а за ценотичною приуроченістю - лісові $(23,8 \%)$, лучні $(18,6 \%)$ та узлісні $(17,5 \%)$ види.

Територія Парку має надзвичайно велике значення для збереження біорізноманіття Лісостепу, оскільки тут представлені аборигенні місцезростання понад 30 рідкісних та гранично-ареальних видів рослин. Місцезростання кількох рідкісних видів, зокрема Pulsatilla grandis i Stipa pennata, нині втрачені і $є$ перспективними для репатріації.

Iз середини XIX ст. до нашого часу Дендрологічний парк «Олександрія», як і деякі інші давні інтродукційні установи, став осередком розповсюдження низки адвентивних видів рослин, зокрема Asclepias syriaca, Galinsoga parviflora, Oxalis stricta. В ході дослідження відзначено подібність багатьох характеристик спонтанної флори «Олександрії» $з$ ознаками спонтанної флори НБС імені М.М. Гришка.

${ }^{69}$ Протопопова, Шевера, 2019. 
3 огляду на велике багатство, що дає змогу підкріпити отримані дані великою вибіркою, ці обидві флори можна розглядати як еталонні спонтанні флори інтродукційних осередків.

\section{КОНСПЕКТ ФЛОРИ}

Умовні позначення: cult. - культурна флора, erg - втікач із культури, extinct - зниклий, microspecies - мікровид, native - аборигенний, not confirmed - не підтверджено, not stable - нестабільний компонент, xen ксенофіт, xen-erg - ксено-ергазіофіт.

\section{ХВОЩI (EQUISETOPSIDA)}

EQUISETACEAE

1. Equisetum arvense L. - native

2. Equisetum palustre L. - native

\section{ПАПОРОТІ}

(POLYPODIOPSIDA)

ASPLENIACEAE

3. Asplenium septentrionale (L.)

Hoffm. - native

4. Athyrium filix-femina (L.)

Roth. - native

5. Cystopteris fragilis (L.) Bernh.

- native

* Onoclea struthiopteris (L.)

Roth (Matteuccia struthiopteris

(L.) Tod. ). - not spont. (cult.)

DENNSTAEDTIACEAE

6. Pteridium pinetorum C.N.Page

\& R.R.Mill (Pteridium aquilinum

auct. non (L.) Kuhn). - native

POLYPODIACEAE

7. Dryopteris carthusiana (Vill.)

H.P.Fuchs. - native

8. Dryopteris filix-mas (L.)

Schott. - native

\section{ХВОЙНІ}

(PINOPSIDA)

PINACEAE

9. Abies alba Mill. - erg-not

stable

10. Pinus sylvestris L. - erg

TAXACEAE
11. Taxus baccata L. - erg-not stable

КВІТКОВІ РОСЛИНИ

(ANGIOSPERMS),

ОДНОДОЛЬНІ

(MONOCOTS)

ACORACEAE

12. Acorus calamus L. - erg-not stable

ALISMATACEAE

13. Alisma plantago-aquatica $\mathrm{L}$.

- native

14. Sagittaria sagittifolia L. -

native

AMARYLLIDACEAE

15. Allium oleraceum L. - native 16. Allium podolicum Blocki ex Racib. \& Szafer. - native 17. Allium rotundum L. - native 18. Allium sativum L. - erg-not stable

19. Allium scorodoprasum L. erg

20. Allium sphaerocephalon L. native

21. Galanthus nivalis L. - native ARACEAE

22. Lemna minor L. - native

23. Spirodela polyrhiza (L.)

Schleid. - native

ASPARAGACEAE

24. Anthericum ramosum L. native 
25. Asparagus officinalis L. native

26. Convallaria majalis L. native

27. Muscari neglectum Guss. ex

Ten. - native

28. Ornithogalum orthophyllum

Ten. subsp. kochii (Parl.) Zahar. native

29. Polygonatum latifolium

(Jacq.) Desf. - native

30. Polygonatum multiflorum (L.)

All. - native

31. Polygonatum odoratum

(Mill.) Druce. - native

32. Scilla bifolia L. - native

ASPHODELACEAE

33. Hemerocallis fulva (L.) L. erg-not stable

BUTOMACEAE

34. Butomus umbellatus L. native

CYPERACEAE

35. Bolboschoenus maritimus (L.)

Palla. - native

36. Carex acuta L. - native

37. Carex acutiformis Ehrh. native

38. Carex caryophyllea Latourr. native

39. Carex hirta L. - native

40. Carex hordeistichos Vill. native

41. Carex humilis Leys. - native

42. Carex leporina L. - native

43. Carex michelii Host. - native

44. Carex montana L. - native

45. Carex muricata L. - native

46. Carex pilosa Scop. - native

47. Carex praecox Schreb. native

48. Carex pseudocyperus L. native

49. Carex remota L. - native
50. Carex riparia Curtis. - native 51. Carex rostrata Stokes. native

52. Carex spicata Huds. - native

53. Carex sylvatica Huds. native

54. Carex vesicaria L. - native

55. Carex vulpina L. - native

56. Cyperus flavescens $\mathrm{L}$. -

native

57. Cyperus fuscus L. - native

58. Eleocharis palustris (L.)

Roem. \& Schult. - native

59. Schoenoplectus lacustris (L.)

Palla. - native

60. Scirpus sylvaticus L. - native

HYDROCHARITACEAE

61. Elodea canadensis Michx. erg

62. Hydrocharis morsus-ranae L.

- native

IRIDACEAE

63. Iris aphylla L. (incl. Iris

hungarica Waldst. \& Kit.). native

64. Iris pseudacorus L. - native

JUNCACEAE

65. Juncus articulatus L. - native

66. Juncus compressus Jacq. native

67. Juncus effusus L. - native

68. Juncus tenuis Willd. - xen

69. Luzula campestris (L.) DC. native

70. Luzula multiflora (Ehrh.) Lej.

- native

71. Luzula pallescens Sw. native

LILIACEAE

72. Gagea lutea (L.) Ker Gawl. native

73. Gagea minima (L.) Ker Gawl.

- native 
74. Gagea transversalis Steven (Gagea paczoskii (Zapal.)

Grossh. ). - native

75. Gagea pusilla (F.W.Schmidt)

Schult. \& Schult.f. - native

76. Lilium martagon L. - native

* Tulipa $\times$ hybrida aggr. hort. not spont. (cult.)

MELANTHIACEAE

77. Veratrum nigrum L. - native (extinct)

78. Paris quadrifolia L. - native

ORCHIDACEAE

79. Neottia nidus-avis (L.) Rich.

- native

POACEAE

80. Agropyron cristatum (L.)

Gaertn. (incl. Agropyron pectinatum (M.Bieb.) P.Beauv.).

- native

81. Agrostis capillaris L. - native

82. Agrostis gigantea Roth. -

native

83. Agrostis stolonifera L. -

native

84. Alopecurus pratensis L. -

native

85. Anthoxanthum odoratum L. native

86. Apera spica-venti (L.)

P.Beauv. - xen

87. Arrhenatherum elatius (L.)

P.Beauv. ex J.Presl \& C.Presl. native

88. Avena fatua L. - xen

89. Bothriochloa ischaemum (L.)

Keng. - native

90. Brachypodium pinnatum (L.)

P.Beauv. - native

91. Brachypodium sylvaticum

(Huds.) P.Beauv. - native

92. Briza media L. - native

93. Bromus arvensis L. - xen
94. Bromus benekenii (Lange)

Trimen. - native

95. Bromus carinatus Hook. \&

Arn. - erg-not stable

96. Bromus erectus Huds. - erg-

not stable

97. Bromus hordeaceus L. - xen

98. Bromus inermis Leyss. -

native

99. Bromus squarrosus L. - xen

100. Bromus tectorum L. - xen

101. Calamagrostis epigejos (L.)

Roth. - native

102. Catabrosa aquatica (L.)

P.Beauv. - native

103. Cynodon dactylon (L.) Pers.

- xen-not stable

104. Cynosurus cristatus L. native

105. Dactylis glomerata L. native

106. Deschampsia cespitosa (L.)

P.Beauv. - native

107. Digitaria ischaemum

(Schreb.) Muehl. - xen

108. Digitaria sanguinalis (L.)

Scop. - xen

109. Echinochloa crusgalli (L.)

P.Beauv. - xen

110. Elymus caninus (L.) L. native

111. Elytrigia intermedia (Host)

Nevski. - native

112. Elytrigia repens (L.) Nevski.

- native

113. Eragrostis minor Host. xen

114. Festuca rubra L. - native

115. Festuca rupicola Heuff. native

116. Festuca valesiaca Schleich.

ex Gaudin. - native

117. Glyceria fluitans (L.) R.Br.

- native 
118. Glyceria maxima (C.Hartm.)

Holmb. - native

119. Glyceria striata (Lam.)

Hitchc. - erg-not stable

120. Helictotrichon pubescens

(Huds.) Pilg. - native

121. Hierochloe odorata (L.)

P.Beauv. - native

122. Holcus lanatus L. - native

123. Hordeum murinum L. - xen

124. Hordeum vulgare L. - erg-

not stable

125. Koeleria macrantha

(Ledeb.) Schult. (Koeleria

gracilis Pers.). - native

126. Leersia oryzoides (L.) Sw. native

127. Lolium arundinaceum

(Schreb.) Darbysh. subsp.

orientale (Hack.) G.H.Loos

(Festuca orientalis (Hack.)

Krecz. \& Bobrov). - native

128. Lolium giganteum (L.)

Darbysh. (Festuca gigantea (L.)

Vill.) - native

129. Lolium perenne L. - native

130. Lolium pratense (Huds.)

Darbysh. (Festuca pratensis

Huds.) - native

131. Melica altissima L. - native

132. Melica nutans L. - native

133. Melica picta K.Koch native

134. Melica transsilvanica Schur.

- native

135. Milium effusum L. - native

136. Panicum capillare L. - xen-

not stable

137. Panicum miliaceum L. -

erg-not stable

138. Phleum phleoides (L.)

H.Karst. - native

139. Phleum pratense L. - native
140. Phragmites australis (Cav.)

Trin. ex Steud. - native

141. Poa angustifolia L. - native

142. Poa annua L. - native

143. Poa bulbosa L. - native

144. Poa compressa L. - native

145. Poa nemoralis L. - native

146. Poa palustris L. - native

147. Poa pratensis L. - native

148. Poa remota Forselles. -

native

149. Poa trivialis L. subsp.

trivialis. - native

* P. t. subsp. sylvicola (Guss.)

H.Lindb. - not confirmed

150. Secale cereale L. - erg-not stable

151. Setaria adhaerens (Forssk.)

Chiov. - xen

152. Setaria glauca (L.) P.Beauv.

- xen

153. Setaria verticillata (L.)

P.Beauv. - xen

154. Setaria viridis (L.) P.Beauv. - xen

155. Sorghum bicolor (L.)

Münchh. (incl. Sorghum

saccharatum (L.) Münchh.). -

erg-not stable

156. Stipa capillata L. - native

157. Stipa pennata L. - native

(extinct)

158. Trisetum flavescens (L.)

P.Beauv. - erg-not stable

159. Zizania latifolia (Griseb.)

Hance ex F.Muell. - erg

POTAMOGETONACEAE

160. Potamogeton crispus L. native

161. Potamogeton gramineus L. native

162. Potamogeton natans L. native 
163. Potamogeton nodosus Poir. - native

164. Potamogeton perfoliatus $\mathrm{L}$.

- native

SPARGANIACEAE

165. Sparganium erectum L. native

TYPHACEAE

166. Typha angustifolia L. native

167. Typha latifolia L. - native

\section{ДВОДОЛЬНІ (EUDICOTS) ACERACEAE \\ 168. Acer campestre L. - native 169. Acer negundo L. - erg \\ 170. Acer platanoides L. - native \\ 171. Acer pseudoplatanus L. - erg}

172. Acer tataricum L. - native AMARANTHACEAE

173. Amaranthus albus L. - xen

174. Amaranthus blitoides

S.Watson. - xen

175. Amaranthus caudatus L. erg-not stable

176. Amaranthus cruentus L. erg-not stable

177. Amaranthus

hypochondriacus L. - erg-not

stable

178. Amaranthus retroflexus L. xen

179. Atriplex latifolia Wahlenb. native

180. Atriplex oblongifolia

Waldst. \& Kit. - native

181. Atriplex patula L. - native

182. Atriplex prostrata Boucher ex DC. - xen

183. Atriplex sagittata Borkh. xen

184. Atriplex tatarica L. - xen
185. Chenopodiastrum hybridum (L.) S.Fuentes, Uotila \& Borsch (Chenopodium hybridum L.). xen

186. Chenopodium album L. native

187. Chenopodium opulifolium Schrad. ex W.D.J.Koch \& Ziz. not confirmed

188. Chenopodium strictum Roth.

- xen

189. Chenopodium suecicum

Murr. - xen

190. Kochia scoparia (L.)

Schrad. - erg

191. Lipandra polysperma (L.)

S.Fuentes, Uotila \& Borsch

(Chenopodium polyspermum L.).

- xen

192. Oxybasis urbica (L.)

S.Fuentes, Uotila \& Borsch

(Chenopodium urbicum L.). -

native

ANACARDIACEAE

193. Toxicodendron radicans (L.)

Kuntze. - erg-not stable

APIACEAE

194. Aegopodium podagraria L.

- native

195. Aethusa cynapium L. - xen

196. Anethum graveolens L. -

erg-not stable

197. Angelica archangelica L. native

198. Angelica sylvestris L. native

199. Anthriscus cerefolium (L.)

Hoffm. - xen-erg

200. Anthriscus sylvestris (L.)

Hoffm. - native

201. Bupleurum falcatum L. native

202. Carum carvi L. - native 
203. Chaerophyllum aromaticum

L. - native

204. Chaerophyllum bulbosum L.

- native

205. Chaerophyllum temulum $\mathrm{L}$.

- native

206. Cicuta virosa L. - native

207. Conium maculatum L. - xen

208. Daucus carota L. - native

209. Dichoropetalum carvifolia

(Vill.) Pimenov \& Kljuykov

(Peucedanum carvifolium Vill.).

- native

210. Eryngium campestre L. -

native

211. Eryngium planum L. -

native

212. Falcaria vulgaris Bernh. native

213. Ferulago sylvatica (Besser)

Rchb. - native

214. Heracleum sibiricum L. native

215. Heracleum sosnowskyi

Manden. - erg-not stable

216. Oenanthe aquatica (L.) Poir.

- native

217. Pastinaca sativa L. - native

218. Petroselinum crispum

(Mill.) Fuss. - erg-not stable

219. Peucedanum alsaticum L. native

220. Peucedanum oreoselinum

(L.) Münchh. - native

221. Pimpinella nigra Mill. native

222. Pimpinella saxifraga L. native

223. Seseli annuиm L. - native

224. Seseli libanotis (L.)

W.D.J.Koch (incl. Libanotis

intermedia Rupr.). - native

225. Sium latifolium $\mathrm{L}$. - native
226. Torilis japonica (Houtt.)

DC. - native

APOCYNACEAE

227. Asclepias syriaca L. - erg

228. Vinca minor L. - erg-not

stable

229. Vincetoxicum hirundinaria

Medik. - native

230. Vincetoxicum scandens

Sommier \& Levier. - erg-not

stable

ARISTOLOCHIACEAE

231. Aristolochia clematitis L. native

232. Asarum europaeum L. native

ASTERACEAE

233. Achillea inundata Kondr. native

234. Achillea millefolium $\mathrm{L}$.

subsp. collina (Wirtg.) Oborny

(incl. Achillea submillefolium

Klokov \& Krytzka.). - native

235. Achillea nobilis L. - native

236. Achillea pannonica Scheele.

- native

237. Achillea setacea Waldst. \&

Kit. - native

$*$ A. inundata $\times$ A. pannonica. native

238. Ambrosia artemisiifolia L. xen

239. Ambrosia psilostachya DC.

- erg-not stable

240. Anthemis ruthenica M.Bieb.

- native

* Arctium $\times$ ambiguum Nyman. native

241. Arctium lappa L. - native

242. Arctium minus (Hill) Bernh.

- native

243. Arctium tomentosum Mill. native 
244. Artemisia absinthium L. xen

245. Artemisia annua L. - xen

246. Artemisia austriaca Jacq. native

247. Artemisia campestris L.

subsp. inodora Nyman (incl. A. dniproica Klokov). - native

248. Artemisia genipi Stechm. erg-not stable

249. Artemisia scoparia Waldst. $\&$ Kit. - native (extinct)

250. Artemisia vulgaris L. native

251. Aster bessarabicus Bernh.

ex Rchb. - native (extinct)

252. Bellis perennis L. - erg

253. Bidens cernua L. - native

254. Bidens frondosa L. - xen

255. Bidens tripartita L. - native

256. Calendula officinalis L. erg-not stable

257. Callistephus chinensis (L.)

Nees. - erg-not stable

258. Carduus acanthoides L. -

xen

259. Carduus crispus L. - native

260. Carlina biebersteinii Bernh.

ex Hornem. - native

261. Centaurea cyanus L. - xen

262. Centaurea diffusa Lam. -

xen

263. Centaurea jacea L. - native

264. Centaurea mollis Waldst. \&

Kit. - erg-not stable (extinct)

265. Centaurea pannonica

(Heuff.) Hayek. - native

266. Centaurea scabiosa L.

subsp. apiculata (Ledeb.)

Mikheev. - native

267. Centaurea scabiosa subsp.

adpressa (Ledeb.) Gugler. -

native
268. Centaurea stenolepis

A.Kern. - native

269. Centaurea stoebe L.

(C. pseudomaculosa Dobrocz.). native

* Centaurea stricta Waldst. \&

Kit. - not spont. (cult.)

270. Chondrilla juncea L. -

native

271. Chondrilla latifolia M.Bieb.

- native

272. Cichorium intybus L. - xen

273. Cirsium arvense (L.) Scop.native

274. Cirsium decussatum Janka. native

275. Cirsium oleraceum (L.)

Scop. - native

276. Cirsium palustre (L.) Scop.

- native

277. Cirsium vulgare (Savi) Ten.

- native

278. Coreopsis grandiflora Hogg

ex Sweet. - erg-not stable

279. Cota tinctoria (L.) J.Gay

(incl. Anthemis subtinctoria

Dobrocz.). - native

280. Crepis foetida L. subsp.

rhoeadifolia (M.Bieb.) Celak. -

native

281. Crepis tectorum L. - native

282. Echinops sphaerocephalus

L. - native

283. Erigeron annuus (L.) Pers.

(Phalacroloma annuum (L.)

Dumort.). - xen

284. Erigeron canadensis L.

(Conyza canadensis (L.)

Cronquist). - xen

285. Eupatorium cannabinum L.

- native

286. Filago arvensis L. - native

287. Galatella linosyris (L.)

Rchb.f. - native 
288. Galinsoga parviflora Cav. xen

289. Helianthus annuus L. - ergnot stable

290. Helianthus tuberosus L. -

erg-not stable

291. Helichrysum arenarium (L.)

Münchh. - native

292. Heliopsis helianthoides (L.)

Sweet subsp. scabra (Dunal)

T.R.Fisher. - erg-not stable

* Hieracium silvularum Jord. ex

Boreau. - not spont. (cult.?)

293. Hieracium umbellatum L. native

294. Hypochaeris maculata L. native

295. Inula britannica L. - native

296. Inula helenium L. - native

297. Inula hirta L. - native

298. Iva xanthiifolia Nutt. - erg

299. Jacobaea vulgaris Gaertn.

(Senecio jacobaea L.). - native

300. Jurinea cyanoides (L.)

Rchb. - native (extinct)

301. Lactuca muralis (L.) E.Mey.

(Mycelis muralis (L.) Dumort.) native

302. Lactuca quercina L. - native

303. Lactuca serriola L. - xen

304. Lapsana communis L. -

native

305. Leontodon autumnalis L. native

306. Leontodon hispidus L. native

307. Leucanthemum vulgare

Lam. - native

308. Matricaria chamomilla L.

(Chamomilla recutita (L.)

Rauschert). - erg

309. Matricaria discoidea DC.

(Chamomilla suaveolens (Pursh)

Rydb.). - xen
310. Omalotheca sylvatica (L.)

Sch.Bip. \& F.W.Schultz

(Gnaphalium sylvaticum

L.) - native

311. Onopordum acanthium L. xen

- Petasites hybridus (L.)

G.Gaertn., B.Mey. \& Scherb. not spont. (cult.)

312. Picris hieracioides L. (incl.

Picris rigida Ledeb. ex Spreng.).

- native

313. Pilosella aurantiaca (L.)

F.Schultz \& Sch.Bip. - erg-not

stable (extinct)

314. Pilosella caespitosa

(Dumort.) P.D.Sell \& C.West

(Hieracium pratense Tausch). native

315. Pilosella cymosa (L.)

F.Schultz \& Sch.Bip. - native

316. Pilosella echioides (Lumn.)

F.Schultz \& Sch.Bip. - native

317. Pilosella $\times$ floribunda

(Wimm. \& Grab.) Fr. - native

318. Pilosella officinarum Vaill.

- native

319. Pyrethrum corymbosum (L.)

Scop. - native

320. Tanacetum macrophyllum

(Waldst. \& Kit.) Sch.Bip. - erg-

not stable (extinct)

321. Rudbeckia laciniata L. -

erg-not stable (extinct)

322. Scorzonera purpurea L. native

323. Senecio sarracenicus L. native

324. Senecio vernalis Waldst.

$\&$ Kit. - native

325. Senecio vulgaris L. - xen»

326. Silphium perfoliatum L. -

erg-not stable

327. Solidago canadensis L. - erg 
328. Solidago virgaurea L. native

329. Sonchus arvensis subsp.

uliginosus (M .Bieb.) Nyman. -

native

330. Sonchus oleraceus L. - xen

331. Sonchus palustris L. - native

332. Symphyotrichum dumosum

(L.) G.L. Nesom (Aster dumosus

Hoffm. auct.). - erg-not stable

333. Symphyotrichum novi-belgii

(L.) G.L.Nesom (Aster novi-

belgii L). - erg-not stable

334. Symphyotrichum $\times$ salignum

(Willd.) G.L.Nesom (Aster $\times$

salignus Willd.). - erg-not stable

335. Tagetes erecta L. - erg-not

stable

336. Tanacetum vulgare L. native

337. Taraxacum officinale

F.H.Wigg.

338. Taraxacum scanicum

Dahlst. (T. erythrospermum auct. non Andrz.). - native

339. Taraxacum serotinum

(Waldst. \& Kit.) Poir. - native

340. Telekia speciosa (Schreb.)

Baumg. - erg-not stable

341. Tragopogon dubius Scop.

subsp. major (Jacq.) Vollm. -

native

342. Tragopogon orientalis L. native

343. Tripleurospermum inodorum

(L.) Sch.Bip. - xen

344. Tussilago farfara L. - native

345. Xanthium albinum (Widder)

Scholz \& Sukopp. - xen

BALSAMINACEAE

346. Impatiens noli-tangere L. native

347. Impatiens parviflora DC. xen
BERBERIDACEAE

348. Berberis vulgaris $\mathrm{L}$. - native BETULACEAE

349. Alnus glutinosa (L.) Gaertn.

- native

350. Betula pendula Roth. -

native

351. Carpinus betulus L. - native

352. Corylus avellana L. - native

BORAGINACEAE

* Anchusa ochroleuca M.Bieb.

(Anchusa popovii (Gusul.)

Dobrocz.). - not spont. (cult.?)

353. Anchusa officinalis L. - xen

354. Asperugo procumbens L. native

355. Buglossoides arvensis (L.)

I.M.Johnst. - xen

356. Cerinthe minor L. - native

357. Cynoglossum officinale L. -

xen

358. Cynoglottis barrelieri (All.)

Vural \& Kit Tan (Anchusa

barrelieri (All.) Vitm.) - native

(extinct)

359. Echium vulgare L. - native

* Heliotropium europaeum L. -

(cult.?) (extinct)

360. Lithospermum officinale L. native

361. Myosotis arvensis (L.) Hill.

- xen

362. Myosotis micrantha Pall. ex

Lehm. - native

363. Myosotis scorpioides L. native

364. Myosotis sparsiflora

J.C.Mikan ex Pohl. - native

365. Myosotis sylvatica Ehrh. ex

Hoffm. - erg-not stable

366. Nonea pulla (L.) DC. native

367. Omphalodes scorpioides

(Haenke) Schrank. - native 
368. Phacelia tanacetifolia

Benth. - erg-not stable

369. Pontechium maculatum (L.)

Böhle \& Hilger (Echium

russicum S.G.Gmel.). - native

(extinct)

370. Pulmonaria angustifolia L. native

371. Pulmonaria mollis Wulfen

ex Hornem. - native

372. Pulmonaria obscura

Dumort. - native

373. Symphytum asperum

Lepech. - erg-not stable

374. Symphytum officinale L. native

BRASSICACEAE

375. Alliaria petiolata (M.Bieb.)

Cavara \& Grande. - native

376. Alyssum desertorum Stapf. native

377. Arabidopsis thaliana (L.)

Heynh. - native

378. Armoracia rusticana

P.Gaertn., B.Mey. \& Scherb. -

erg-not stable

379. Berteroa incana (L.) DC. native

380. Brassica napus L. - erg-not stable

381. Brassica rapa L. subsp.

campestris (L.) A.R.Clapham. -

xen

382. Bunias orientalis L. - xen

383. Capsella bursa-pastoris (L.)

Medik. - xen

384. Cardamine amara L. -

native

385. Cardamine dentata Schult. native

386. Cardamine impatiens L. native

387. Cardamine parviflora L. native
388. Descurainia sophia (L.)

Webb ex Prantl. - xen

389. Diplotaxis muralis (L.) DC.

- xen

390. Draba nemorosa L. - native

391. Erophila verna (L.) DC. -

native

392. Erysimum canescens Roth. native

393. Erysimum cheiranthoides L. - xen

394. Erysimum marschallianum

Andrz. ex DC. - native

395. Hesperis matronalis L. -

erg-not stable

396. Lepidium densiflorum

Schrad. - xen

397. Lobularia maritima (L.)

Desv. - erg-not stable

398. Rorippa amphibia (L.)

Besser. - native

399. Rorippa austriaca (Crantz)

Besser. - native

400. Rorippa palustris (L.)

Besser. - native

401. Rorippa sylvestris (L.)

Besser. - native

402. Sinapis alba L. - erg-not

stable

403. Sinapis arvensis L. - xen

404. Sisymbrium loeselii L. - xen

405. Sisymbrium officinale (L.)

Scop. - xen

406. Sisymbrium orientale L. -

xen

407. Sisymbrium strictissimum L.

- native

408. Thlaspi arvense L. - xen

409. Turritis glabra L. - native

CAMPANULACEAE

410. Asyneuma canescens

(Waldst. \& Kit.) Griseb. \&

Schenk. - native 
411. Campanula bononiensis L. native

412. Campanula glomerata L. native

413. Campanula latifolia L. native

414. Campanula patula L. native

415. Campanula persicifolia L. native

416. Campanula rapunculoides

L. - native

417. Campanula rotundifolia L. native

418. Campanula sibirica L. native

419. Campanula trachelium L. native

CANNABACEAE

420. Cannabis sativa L. (incl.

Cannabis ruderalis Janisch.). -

erg

421. Celtis occidentalis L. - ergnot stable

422. Humulus lupulus L. - native 423. Humulus scandens (Lour.)

Merr. (Humulus japonicus

Siebold \& Zucc.). - erg-not stable CAPRIFOLIACEAE

424. Dipsacus laciniatus L. native

425. Knautia arvensis (L.) Coult.

- native

426. Lonicera $\times$ notha Zabel. erg-not stable

427. Lonicera caprifolium L. erg-not stable

428. Lonicera ruprechtiana

Regel. - erg-not stable

429. Lonicera tatarica L. - erg

430. Scabiosa ochroleuca L. native

431. Valeriana carinata (Loisel.)

Christenh. \& Byng. - native
432. Valeriana officinalis L. native

433. Valeriana pratensis Dierb.

(Valeriana collina Wallr.). -

native

434. Valerianella locusta (L.)

Laterr. - xen-not stable (extinct)

CARYOPHYLLACEAE

435. Arenaria serpyllifolia L. native

436. Cerastium arvense L. native

437. Cerastium holosteoides Fr. native

438. Cerastium semidecandrum

L. - native

439. Dianthus armeria L. -

native

440. Dianthus barbatus L. - erg-

not stable

441. Dianthus capitatus DC. subsp. andrzejowskianus Zapal. native

442. Dianthus deltoides L. native

443. Dianthus membranaceus

Borbás. - native

444. Eremogone micradenia

(P.Smirn.) Ikonn. - native

445. Holosteum umbellatum L. xen

446. Moehringia trinervia (L.)

Clairv. - native

447. Myosoton aquaticum (L.)

Münchh. - native

448. Saponaria officinalis L. -

erg

449. Silene baccifera (L.) Roth

(Cucubalus baccifer L.). - native

450. Silene chalcedonica (L.)

E.H.L.Krause (Lychnis

chalcedonica L.). - erg-not stable (extinct) 
451. Silene eugeniae Kleopow (Otites eugeniae (Kleopow)

Klokov). - native

452. Silene flos-cuculi (L.)

Greuter \& Burdet (Coronaria

flos-cuculi (L.) A.Braun). -

native

453. Silene nutans $\mathrm{L}$. - native

454. Silene vulgaris (Münchh.)

Garcke. - native

455. Spergularia rubra (L.)

J.Presl \& C.Presl. - native

456. Stellaria graminea L. native

457. Stellaria holostea L. - native

458. Stellaria media (L.) Vill. -

native

459. Viscaria vulgaris Röhling. native

CELASTRACEAE

460. Celastrus orbiculatus

Thunb. - erg-not stable

461. Euonymus europaeus L. -

native

462. Euonymus verrucosus Scop.

- native

CERATOPHYLLACEAE

463. Ceratophyllum demersum $\mathrm{L}$.

- native

CONVOLVULACEAE

464. Calystegia sepium (L.) R.Br.

- native

465. Convolvulus arvensis L. -

native

466. Cuscuta epithymum (L.) L. native

467. Cuscuta lupuliformis Krock.

- native

468. Ipomoea purpurea (L.)

Roth. - erg-not stable

469. Ipomoea tricolor Cav. - ergnot stable

CORNACEAE
470. Cornus sanguinea L. subsp. sanguinea (Swida sanguinea (L.) Opiz). - native 471. Cornus sanguinea subsp. australis (C.A.Mey.) Jáv. ( $S$. australis (C.A.Mey.) Pojark. ex Grossh.). - erg 472. Cornus sanguinea subsp. hungarica (Kárpáti) Soó. - ergnot stable

CRASSULACEAE 473. Hylotelephium maximum (L.) Holub. - native 474. Phedimus spurius (M.Bieb.) 't Hart (Sedum spurium M.Bieb.). - erg-not stable (extinct)

475. Sedum acre L. - native 476. Sedum pallidum M.Bieb. erg-not stable

477. Sedum sexangulare L. xen-erg- not stable CUCURBITACEAE

478. Citrullus lanatus (Thunb.)

Matsum. \& Nakai. - erg-not stable

479. Cucumis sativus L. - erg-not stable

480. Echinocystis lobata (Michx.)

Torr. \& A.Gray. - xen

481. Thladiantha dubia Bunge. erg

EUPHORBIACEAE

482. Euphorbia cyparissias L. native

483. Euphorbia esula L. - native 484. Euphorbia helioscopia L. xen

485. Euphorbia peplus L. - xen 486. Euphorbia virgata Waldst. $\&$ Kit. - native 487. Mercurialis perennis L. native

FABACEAE

488. Amorpha fruticosa L. - erg 
489. Astragalus cicer L. - native 490. Astragalus glycyphyllos L. native

491. Astragalus onobrychis L. native

492. Chamaecytisus ruthenicus

(Fisch. ex Wol.) Klásk. - native

493. Cytisus austriacus L. -

native

* Cytisus scoparius (L.) Link (Sarothamnus scoparius (L.)

Wimm. ex W.D.J.Koch), - not spont. (cult.)

494. Genista tinctoria L. - native 495. Gleditsia triacanthos L.erg-not stable

496. Gymnocladus dioicus (L.)

K.Koch. - erg-not stable

497. Lathyrus sylvestris L. native

498. Lathyrus tuberosus L. - erg 499. Lotus corniculatus L. (incl. var. hirsutus Koch). - native 500. Lupinus perennis L. - erg 501. Lupinus polyphyllus Lindl. erg-not stable

502. Medicago falcata $\mathrm{L}$. (incl. Medicago romanica Prodan). native

503. Medicago lupulina L. native

504. Medicago minima (L.)

Bartal. - native (extinct)

505. Medicago sativa L. - erg

506. Medicago $\times$ varia Martyn. erg

507. Melilotus albus Medik. native

508. Melilotus officinalis (L.)

Lam. - native

509. Onobrychis arenaria (Kit.)

DC. (incl. Onobrychis viciifolia

auct. non Scop.). - native
510. Robinia pseudoacacia L. erg-not stable

511. Securigera varia (L.)

Lassen. - native

512. Trifolium alpestre L. native

513. Trifolium arvense L. native

514. Trifolium campestre Schreb.

(Trifolium agrarium L. auct.). native

515. Trifolium fragiferum L. native

516. Trifolium medium L. native

517. Trifolium montanum L. native

518. Trifolium pratense L. native

519. Trifolium repens L. - native 520. Vicia cracca L. - native 521. Vicia sativa L. subsp. nigra (L.) Ehrh. (Vicia angustifolia Reichard). - xen

522. Vicia sepium L. - native 523. Vicia tenuifolia Roth. native

524. Vicia tetrasperma (L.)

Schreb. - xen

FAGACEAE

525. Quercus macranthera Fisch. \& C.A.Mey. ex Hohen. - erg-not stable

526. Quercus robur L. - native

527. Quercus rubra L. - erg

GENTIANACEAE

528. Centaurium pulchellum

(Sw.) Hayek ex Hand.-Mazz.,

Stadlm., Janch. \& Faltis. - native

529. Gentiana cruciata L. native (extinct)

GERANIACEAE

530. Erodium cicutarium (L.)

L'Her. - native 
531. Geranium molle L. - xen

532. Geranium palustre L. native

533. Geranium phaeum L. native

534. Geranium pratense L. native

535. Geranium pusillum L. - xen 536. Geranium pyrenaicum

Burm.f. - erg-not stable (extinct)

537. Geranium robertianum L. native

538. Geranium sanguineum L. native

539. Geranium sibiricum L. - erg * [G. s. subsp. popovii

Tzvelev]. - forma

GROSSULARIACEAE

540. Ribes nigrum $\mathrm{L}$. - native

541. Ribes uva-crispa L. - erg-

not stable

HALORAGACEAE

542. Myriophyllum verticillatum

L. - native

HYPERICACEAE

543. Hypericum perforatum L. native

JUGLANDACEAE

544. Juglans cinerea L. - native

545. Juglans mandshurica

Maxim. - erg-not stable

546. Juglans nigra L. - erg-not stable

547. Juglans regia L. - erg

LAMIACEAE

548. Ajuga genevensis L. - native

549. Ballota nigra L. - xen

550. Clinopodium acinos (L.)

Kuntze (Acinos arvensis (Lam.)

Dandy). - native

* Clinopodium menthifolium

(Host) Merino. - not spont.

(cult.?) (extinct)
551. Clinopodium vulgare L. native

552. Elsholtzia ciliata (Thunb.)

Hyl. - erg

553. Galeopsis bifida Boenn. native

554. Galeopsis speciosa Mill. native

555. Glechoma hederacea L. native

556. Glechoma hirsuta Waldst. \&

Kit. - native

557. Lamium album L. - xen

558. Lamium amplexicaule L.-

xen

559. Lamium galeobdolon (L.) L.

- native

560. Lamium galeobdolon subsp.

montanum (Pers.) Hayek. - erg-

not stable

561. Lamium maculatum (L.) L. native

562. Lamium purpureum L. - xen

563. Leonurus quinquelobatus

Gilib. - native

564. Lycopus europaeus L. -

native

565. Lycopus exaltatus L.f. -

native

* Marrubium vulgare L. - not

confirmed

566. Mentha aquatica $\mathrm{L}$. - native

567. Mentha longifolia (L.) L. native

568. Nepeta cataria L. - erg-not stable

569. Nepeta pannonica L. -

native

570. Nepeta racemosa Lam. -

erg-not stable

571. Origanum vulgare L. -

native

572. Phlomis tuberosa L. - native

573. Prunella vulgaris L. - native 
574. Salvia nemorosa L. - native 575. Salvia pratensis L. - native 576. Salvia verticillata $\mathrm{L}$. native

577. Scutellaria altissima L. native

578. Scutellaria galericulata L. native

579. Stachys aпnиа (L.) L. - xen

580. Stachys officinalis (L.)

Trevis. - native

581. Stachys palustris L. - native

582. Stachys recta L. - native

583. Stachys sylvatica L. - native

584. Teucrium chamaedrys L. native

585. Thymus pannonicus All.

(Thymus marschallianus Willd.). - native

586. Thymus pulegioides L. -

erg-not stable (extinct)

LINACEAE

587. Linum flavum L. - native (extinct)

588. Linum perenne L. - native (extinct)

LYTHRACEAE

589. Lythrum salicaria L. native

MALVACEAE

590. Abutilon theophrasti Medik.

- erg-not stable (extinct)

591. Alcea rosea L. - erg-not

stable

592. Alcea rugosa Alef. - erg-not stable

593. Althaea officinalis L. - erg

594. Hibiscus trionum L. - xen

(extinct)

595. Malva neglecta Wallr. - xen

596. Malva pusilla Sm. - xen

597. Malva sylvestris L. - erg

598. Malva thuringiaca (L.) Vis.

- native
MENISPERMACEAE

599. Menispermum dauricum

DC. - erg-not stable

MORACEAE

600. Morus alba L. - erg

NYMPHAEACEAE

601. Nymphaea alba L. - native

602. Nuphar lutea (L.) Sm. -

native

OLEACEAE

603. Fraxinus excelsior L. -

native

604. Fraxinus pennsylvanica

Marshall. (incl. Fraxinus

lanceolata Borkh.). - erg

605. Ligustrum vulgare L. - erg

606. Syringa vulgaris L. - erg-not

stable

ONAGRACEAE

607. Chamerion angustifolium

(L.) Holub. - native

608. Epilobium hirsutum L. -

native

609. Epilobium palustre L. native

610. Epilobium parviflorum

Schreb. - native

611. Epilobium tetragonum L. native

612. Oenothera biennis L. - xen

* Oenothera rubricaulis Kleb. -

microspecies, xen

OROBANCHACEAE

613. Melampyrum nemorosum L.

- native

614. Orobanche caryophyllacea

Sm. - native

615. Pedicularis kaufmannii

Pinzger. - native

616. Rhinanthus minor L. -

native

OXALIDACEAE

* Oxalis acetosella L. - not

confirmed (cult.?) 
617. Oxalis corniculata L. - xen 618. Oxalis dillenii Jacq. - xen 619. Oxalis stricta L. - xen PAPAVERACEAE 620. Chelidonium majus L. native 621. Corydalis cava (L.)

Schweigg. \& Körte. - native 622. Corydalis solida (L.) Clairv. - native 623. Fumaria schleicheri Soy.Will. - xen 624. Fumaria vaillantii Loisel. xen

625. Papaver dubium L. - xen 626. Papaver orientale L. - ergnot stable 627. Papaver rhoeas L. - xen-erg 628. Papaver somniferum L. erg-not stable

PLANTAGINACEAE 629. Chaenorhinum minus (L.)

Lange. - native

630. Digitalis grandiflora Mill. native

631. Hippuris vulgaris $\mathrm{L}$. - native 632. Linaria vulgaris Mill. native 633. Plantago lanceolata L. native

634. Plantago major L. - native 635. Plantago media L. - native 636. Plantago media subsp. stepposa (Kuprian.) Soó. - native 637. Veronica anagallis-aquatica L. - native

638. Veronica arvensis L. - xen 639. Veronica austriaca L. native 640. Veronica beccabunga L. native

641. Veronica chamaedrys L. native
642. Veronica hederifolia L. native

643. Veronica jacquinii Baumg. native

644. Veronica longifolia L. native

645. Veronica officinalis L. native

646. Veronica persica Poir. - erg 647. Veronica polita Fr. - xen 648. Veronica prostrata L. native

649. Veronica spicata L. s.str. native

650. Veronica spuria L. - native

651. Veronica teucrium L. native

652. Veronica verna $\mathrm{L}$. - native

POLYGALACEAE

653. Polygala comosa Schkuhr. native

POLYGONACEAE

654. Fallopia convolvulus (L.)

A.Love. - xen

655. Persicaria amphibia (L.)

Delarbre - native

656. Persicaria hydropiper (L.)

Delarbre. - native

657. Persicaria maculosa Gray. native

658. Persicaria minor (Huds.)

Opiz. - native

659. Persicaria scabra

(Münchh.) Moldenke. - native

660. Polygonum arenastrum

Boreau. - native

661. Polygonum aviculare L. native

662. Polygonum neglectum

Besser. - native

663. Polygonum rurivagum Jord.

ex Boreau. - native

$* P$. aviculare $\times P$. neglectum. 
664. Reynoutria $\times$ bohemica Chrtek \& Chrtkova. - erg 665. Reynoutria japonica Houtt.

- erg-not stable

666. Rumex acetosella $\mathrm{L}$. - native 667. Rumex confertus Willd. native

668. Rumex crispus L. - native 669. Rumex hydrolapathum Huds. - native

* Rumex longifolius DC. - not confirmed

670. Rumex obtusifolius L. subsp. sylvestris (Lam.) Celak. - native 671. Rumex patientia L. - erg 672. Rumex sanguineus L. native

673. Rumex thyrsiflorus Fingerh.

- native

PORTULACACEAE

674. Portulaca grandiflora Hook.

- erg-not stable

675. Portulaca oleracea L. .-

xen

PRIMULACEAE

676. Anagallis arvensis L. - xen

677. Cyclamen purpurascens

Mill. (Cyclamen europaeum L. ).

- erg-not stable

678. Lysimachia nummularia L. native

679. Lysimachia punctata L. erg-not stable

680. Lysimachia vulgaris L. native

681. Primula elatior (L.) Hill. -

erg-not stable

682. Primula veris L. - native

RANUNCULACEAE

683. Actaea spicata L. - native

684. Adonis vernalis $\mathrm{L}$. - native

685. Anemone ranunculoides L. native
686. Anemone sylvestris L. native

687. Aquilegia vulgaris L. - ergnot stable 688. Caltha palustris L. - native * C.p. f. cornuta (Schott, Nyman $\&$ Kotschy) Huth. 689. Ceratocephala testiculata (Crantz) Bess. - native 690. Clematis integrifolia $\mathrm{L} .-$ native (extinct)

691. Clematis recta $\mathrm{L}$. - native

692. Clematis vitalba L. - erg 693. Clematis viticella L. - ergnot stable

694. Consolida regalis Gray. xen

695. Ficaria verna Huds. - native * Hepatica nobilis Schreb. - not spont. (cult.)

696. Isopyrum thalictroides L. native

697. Pulsatilla grandis Wender. native (extinct)

698. Pulsatilla pratensis (L.)

Mill. - native

699. Ranunculus acris L. - native

700. Ranunculus auricomus L. native

701. Ranunculus cassubicus L. native

702. Ranunculus circinatus Sibth.

- native

703. Ranunculus illyricus L. native

704. Ranunculus lanuginosus L. native

705. Ranunculus polyanthemos

L. - native

706. Ranunculus repens L. -

native

707. Ranunculus sceleratus L. native

708. Thalictrum minus L. - native 
RESEDACEAE

709. Reseda lutea L. - xen

710. Reseda luteola L. - erg-not stable

\section{RHAMNACEAE}

711. Frangula alnus Mill. native

712 . Rhamnus cathartica L. native

ROSACEAE

713. Agrimonia eupatoria L. subsp. eupatoria. - native 714. Agrimonia eupatoria subsp. grandis (Andrz. ex C.A.Mey.)

Bornm. - native

* Aruncus dioicus (Walter)

Fernald. - not confirmed (cult.?)

715. Crataegus coccinea L. erg-not stable

716. Crataegus flabellata (Bosc

ex Spach) K.Koch. - erg-not stable

717. Crataegus $\times$ kyrtostyla

Fingerh. - native

718. Crataegus monogyna L.

(incl. Crataegus lipskyi Klokov).

- native

719. Crataegus rhipidophylla

Gand. - native

720. Crataegus submollis Sarg. erg-not stable

721. Duchesnea indica

(Andrews) Focke. - erg-not

stable

722. Filipendula ulmaria (L.)

Maxim. - native

723. Filipendula vulgaris

Münchh. - native

724. Fragaria moschata

Duchesne ex Weston. - erg-not stable

725. Fragaria vesca $\mathrm{L}$. - native

726. Fragaria viridis Duchesne subsp. viridis. - native
727. Fragaria viridis subsp. campestris (Steven) Pawł. native

728. Geum rivale L. - native 729. Geum urbanum L. - native 730. Malus domestica (Suckow) Borkh. - erg

731. Malus sylvestris (L.) Mill. native

732. Potentilla alba L. - native

733. Potentilla anserina L. native

734. Potentilla argentea L. native

735. Potentilla canescens Besser. - native

736. Potentilla heptaphylla L. native

737. Potentilla neglecta Baumg.

- native

738. Potentilla patula Waldst. \&

Kit. - native

739. Potentilla recta L. subsp.

obscura (Willd.) Arcang. - native

740. Potentilla recta subsp.

pilosa (Willd.) Rchb.f. ex Rothm.

- native

741. Potentilla reptans L. native

742. Potentilla supina $\mathrm{L}$. - native

743. Prunus armeniaca L. - erg

744. Prunus avium (L.) L.

(Cerasus avium (L.) Münchh.). native

745. Prunus cerasifera Ehrh. erg

746. Prunus cerasus L. (Cerasus vulgaris Mill.). - erg

747. Prunus fruticosa Pall.

(Cerasus fruticosa (Pall.)

Woronow). - native (extinct)

748. Prunus insititia L. - erg-not stable 
749. Prunus padus L. (Padus avium Mill.). - native

750. Prunus spinosa L. subsp. dasyphylla (Schur) Domin (Prunus stepposa Kotov). native

751. Pyrus communis L. - erg-not stable

752. Pyrus pyraster (L.) Burgsd. - native

753. Rosa canina L. - native

754. Rosa corymbifera Borkh. native

755. Rosa podolica Tratt. (Rosa biserrata Mérat ). - native

756. Rosa rubiginosa L. - native

757. Rosa tomentosa $\mathrm{Sm}$. - native

758. Rosa villosa L. - native

759. Rubus caesius L. - native

760. Rubus idaeus L. - native

761. Sanguisorba minor Scop.

(Poterium sanguisorba L.). - ergnot stable (extinct)

762. Sorbus aucuparia L. native

RUBIACEAE

763. Asperula cynanchica L. native

764. Cruciata glabra (L.) Opiz. native

765. Galium album Mill. - native

* Galium anisophyllon Vill. s.l. not spont. (cult.)

766. Galium aparine L. - native

767. Galium boreale L. - native

768. Galium intermedium Schult.

- native

769. Galium mollugo L. - native

770. Galium palustre L. - native

771. Galium tinctorium L. native

772. Galium verum L. - native RUTACEAE
773. Phellodendron amurense Rupr. - erg-not stable 774. Ptelea trifoliata L. - erg-not stable

SALICACEAE

775. Populus alba L. - native

776. Populus $\times$ canadensis

Moench. - erg

777. Populus $\times$ canescens

(Aiton) Sm. - native

778. Populus nigra L. - native

779. Populus tremula L. - native

780. Salix alba L. - native

781. Salix caprea L. - native

782. Salix cinerea L. - native

783. Salix fragilis L. - erg-not

stable

784. Salix purpurea L. - native

785. Salix triandra L. - native

786. Salix viminalis L. - native

SANTALACEAE

787. Viscum album L. - native

SAPINDACEAE

788. Aesculus hippocastanum L.

- erg-not stable

SAXIFRAGACEAE

789. Chrysosplenium

alternifolium L. - native

SCROPHULARIACEAE

790. Scrophularia nodosa L. native

791. Scrophularia umbrosa

Dumort. - native

792. Verbascum lychnitis L. native

793. Verbascum nigrum L. native

794. Verbascum phlomoides L. native

795. Verbascum thapsus L. native

SIMAROUBACEAE

796. Ailanthus altissima (Mill.)

Swingle. - erg 
SOLANACEAE

797. Datura stramonium L. - xen

798. Hyoscyamus niger L. - xen

799. Lycium barbarum L. - erg

800. Lycopersicon esculentum

Mill. - erg-not stable

801. Petunia $\times$ hybrida (Hook.)

Regel. - erg-not stable

802. Physalis alkekengi L. -

native

803. Solanum dulcamara L. -

native

804. Solanum nigrum L. subsp.

nigrum. - xen

805. Solanum nigrum subsp.

schultesii (Opiz) Wessely. - xen

TILIACEAE

806. Tilia cordata Mill. - native

807. Tilia dasystyla Steven subsp.

caucasica (V. Engl.) Pigott. -

erg-not stable

808. Tilia $\times$ europaea L. - erg

809. Tilia platyphyllos Scop. -

erg-not stable

ULMACEAE

810. Ulmus glabra Huds. - native

811. Ulmus laevis Pall. - native

812. Ulmus minor Mill. - native

URTICACEAE

813. Urtica dioica $\mathrm{L}$. - native

814. Urtica galeopsifolia Wierzb.

ex Opiz. - native

815. Urtica urens L. - xen

VERBENACEAE

816. Verbena officinalis L. - xen

VIBURNACEAE

817. Adoxa moschatellina L. native

818. Sambucus ebulus L. - native

819. Sambucus nigra L. - native

820. Viburnum lantana L. native

821. Viburnum opulus L. - native VIOLACEAE
822. Viola arvensis Murray. xen

823. Viola canina L. - native

824. Viola hirta L. - native

825. Viola mirabilis L. - native

826. Viola odorata L. - native

* Viola odorata aggr. cv. - xen

827. Viola suavis M.Bieb. -

native

828. Viola tricolor L. subsp.

matutina (Klokov) Valentine. -

native

VITACEAE

829. Parthenocissus inserta

(A.Kern.) Fritsch. - erg

830. Vitis vulpina L. - erg

Помилково наведені та не

підтверджені таксони

Умовні позначення:

erroneous definition -

помилково визначений таксон,

not confirmed -

не підтверджено, questionable

designation - сумнівна вказівка.

Achillea millefolium L. -

erroneous definition

Anemone nemorosa L. -

erroneous definition

Astragalus exscapus L. -

erroneous definition

Bidens radiata Thuill. -

erroneous definition

Cardamine pratensis L. - not

confirmed

Carex davalliana Sm. -

erroneous definition

Centaurea scabiosa L. -

erroneous definition

Cephalaria litvinovii Bobrov. erroneous definition

Cerastium glomeratum Thuill. questionable designation 
Chamaecytisus lindemannii (Krecz.) Klásk. - not confirmed Equisetum sylvaticum L. questionable designation

Equisetum variegatum Schleich.

ex F.Weber \& D.Mohr questionable designation Eremogone biebersteinii (D.F.K.

Schltdl.) Holub. - erroneous definition

Erodium beketowii Schmalh. cult.?

Festuca ovina L. - not confirmed Festuca tenuifolia Sibth. erroneous definition

Galatella villosa (L.) Rchb.f. erroneous definition

Hypericum montanum L. erroneous definition

Jurinea salicifolia Gruner - not confirmed

Lysimachia verticillata (Greene)

Hand.-Mazz. - erroneous

definition

Morus nigra L. - erroneous

definition

Papaver argemone L. -

erroneous definition

Parthenocissus quinquefolia (L.)

Planch. - erroneous definition

Peucedanum cervaria (L.)

Lapeyr. - erroneous definition

Phytolacca acinosa Roxb. erroneous definition
Pulmonaria officinalis L. erroneous definition

Reynoutria sachalinensis

(F.Schmidt ex Maxim.) Nakai. erroneous definition

Rumex acetosa L. - erroneous

definition

Sedum hispanicum L. - erroneous definition

Silaum silaus (L.) Schinz \&

Thell. - erroneous definition

Silene borysthenica (Gruner)

Walters (Otites borysthenica

(Gruner) Klokov). - not

confirmed

Silphium terebinthinaceum Jacq.

- erroneous definition

Sonchus arvensis L. - not

confirmed

Stellaria nemorum L. - erroneous definition

Stipa lessingiana Trin. \& Rupr. not confirmed

Toxicodendron pubescens Mill. erroneous definition

Valerianella rimosa Bast. - not

confirmed

Veronica opaca Fr. - erroneous

definition

Viola $\times$ hybrida hort. -

incomprehensible taxon

Viola tricolor L. - erroneous

definition

Woodsia alpina (Bolton) Gray. erroneous definition

\section{АНОТАЦІЯ}

Державний дендрологічний парк «Олександрія» НАН України (м. Біла Церква) - це один із найперших інтродукційних осередків нашої країни. Видове різноманіття рослин на його території здавна привертало увагу флористів, а сьогодні потребувало інвентаризації. За результатами дослідження, проведеного у 2017-2020рр., встановлено повний список спонтанної флори Парку. Проаналізовано структуру флори, iї аборигенну та адвентивну фракції, проведено порівняння 3 флорами інших 
інтродукційних осередків. В ході інвентаризації уточнено повний склад рідкісних і зниклих видів флори, а також перелік таксонів, які в різний час були наведені для території Парку помилково. Проаналізовано видовий склад інвазійно-активних видів рослин.

\section{ЛІТЕРАТУРА}

1. Андрик Є.Й., Балог Л., Шевера М.В. Humulus japonicus Siebold. et Zucc. (Cannabaceae) - новий адвентивний вид флори України. Український ботанічний журнал. 2010. Т. 67. № 3. С. 438-443.

2. Базинер Ф.И. О растительности и климате Киевской губернии. Журнал министерства государственных имуществ. 1853. Кн. 2. C. 1-46.

3. Білик Г.І. Лучні степи. Рослинність УРСР. Степи. Кам'янисті відслонення. Піски / за ред. А.І. Барбарича. Київ : Наукова думка, 1973. C. 33-94.

4. Бортняк М.М. Матеріали до флори Київської області. Український ботанічний журнал. 1975. Т. 32. № 4. С. 445-448.

5. Виноградова Ю.К., Майоров С.Р., Бочкин В.Д. Влияние чужеродных видов растений на динамику флоры территории Главного ботанического сада РАН. Российский журнал биологических инвазий. 2015. № 4. C. 22-41.

6. Гавриленко Н.О., Мойсієнко I.І., Шаповал В.В. Спонтанна флора дендрологічного парку «Асканія-Нова». Bicmі Біосферного заповідника «Асканія-Нова». 2008. Т. 10. С. 49-73.

7. Галкін С.I., Дойко Н.M. Адвентивна фракція трав'янистої рослинності дендропарку «Олександрія» НАН України. Інтродукиія рослин. 2012. № 1. С. 94-104.

8. Гриценко В.В. Лучні степи Київського плато: флора, рослинність, популяції рідкісних видів та охорона : дис. ... канд. біол. наук : спец. 03.00.05. Київ, 2007. 358 с.

9. Гродзінський М.К. Білоцерківщина. Рослинність Білоцерківщини. Труди Білочерківського Краєзнавчого Товариства. 1928. Т. 1. Вип. 4. С. 1-79.

10. Гродзінський М.К. Матеріали до флори Білоцерківщини. Записки Білоцерківського сільськогосподарського політехнікуму. 1929. Т. 1. Вип. 1. С. 9-22.

11. Дерий И.Г. Дендрофлора парка «Александрия» ботанического сада АН УССР. Акклиматизаиия растений. Киев : изд-во АН УССР, 1958. C. $110-132$.

12. Доброчаєва Д.М. Шорстколисті (Boraginales Hutch.) європейської частини СРСР : дис. ... докт. біол. наук. Додаток. Київ, 1977. T. 1. C. 1-305. T. 2. C. 306-624. 
13. Дойко Н.М., Калашнікова Л.В., Рубіс В.Л. Каталог трав'янистих рослин Державного дендрологічного дендропарку «Олександрія» НАН України / за ред. С.І. Галкіна. Біла Церква, 2013. 65 с.

14. Дойко Н.М., Катревич М.В. Трав'янисті ергазіофігофіти в дендропарку «Олександрія». Інтродукиія рослин, збереження та збагачення біорізноманіття в ботанічних садах та дендропарках : матеріали конференції, присвяченій 80-річчю від дня заснування НБС ім. М.М. Гришка. (Київ, 15-17 вересня 2015 р.). Київ, 2015. С. 76-77.

15. Зеров Д.К. До флори Черкаської округи (кол. Черкаський та Чигиринський повіти) Київщини. Вісник Київського ботанічного саду. 1924. Вип. 1. С. 5-26.

16. Прокудин Ю.Н., Вовк А.Г., Петрова О.А. и др. Злаки Украины. Киев : Наукова думка, 1977. 518 с.

17. Бойко Н.С., Дойко Н.М., Драган Н.В. та ін. Каталог деревних рослин Державного дендрологічного дендропарку «Олександрія» НАН України / за ред. С.І. Галкіна. Біла Церква, 2013. 62 с.

18. Клеопов Ю.Д. Анализ флоры широколиственных лесов европейской части СССР / отв. ред. Д.Н. Доброчаева. Киев : Наукова думка, 1990. $352 \mathrm{c.}$

19. Кляшторная Г.В. Папоротник «Страусово перо» - ценное реликтовое и редкое декоративное растение. Восстановление и обогащение парковых ландшафтов на Украине : сборник научных трудов. Киев : Наукова думка, 1981а. С. 99-101.

20. Кляшторная Г.В. Фитоценотическая характеристика травянистой дубравы дендропарка «Александрия» АН УССР. Оптимизаиия структуры парковых насаждений и использованием интродуцентов : сборник научных трудов. Киев : Наукова думка, 1990. С. 27-32.

21. Кляшторная Г.В. Флора южного склона Палиевой горы дендрозаповедника «Александрия» АН УССР - реликт степной растительности Правобережной Лесостепи Украины. Восстановление и обогащение парковых ландмафтов на Украине : сборник научных трудов. Киев : Наукова думка, 1981б. С. 61-69.

22. Котов М.I Адвентивна рослинність на Україні. Вісник природознавства. 1928. № 5-6. С. 267-274.

23. Куземко А.А., Ковтонюк А.І. Таксономічна та екологічна структура спонтанної флори Національного дендрологічного парку «Софіївка» НАН України. Автохтонні та інтродуковані рослини. 2015. Вип. 11. С. 111-120.

24. Левон Ф.М., Драган Н.В., Мордатенко Л.П., Галкін С.I. Природне поновлення хвойних рослин в дендропарку «Олександрія». Біоекологічні аспекти. Інтродукиія $i$ зелене будівництво : збірник наукових праць. Біла Церква : Мустанг, 2000. С. 115-122.

25. Мельник В.I., Баранський О.Р. Генезис та динаміка ареалу Sarothamnus scoparius (Fabaceae) у межах України. Украӥнський 
ботанічний журнал. 2017. Т. 74. № 4. С. 334-346. DOI: $10.15407 / \mathrm{ukrbotj} 74.04 .334$.

26. Небесский А.О. Список древесных и кустарниковых пород растений акклиматизованных в саду графа А. Браницкого близ Киева. Труды отдела ботаники Императорского общества акклиматизации животных и растений. 1899. № 1. С. 122-132.

27. Оксіюк П.В. До питання про поширення адвентивних рослин на Україні. Наукові записки. Орган Київських науково-дослідчих катедр. 1924. T. 2. C. $121-129$.

28. Протопопова В.В. Адвентивні рослини Лісостепу і Степу України. Київ : Наукова думка, 1973. 192 с.

29. Протопопова В.В. Синантропная флора Украины и пути ее развития. Киев : Наукова думка, 1991. 204 с.

30. Протопопова В.В., Шевера М.В. Інвазійні види у флорі України. I. Група високо активних видів. GEO\&BIO. 2019. Vol. 17. P. 116-135. DOI: $10.15407 / \mathrm{gb} .2019 .17 .116$.

31. Рогович А.В. Обозрение семенных и высших споровых растений, входящих в состав флоры губерний Киевского учебного округа: Волынской, Подольской, Киевской, Черниговской и Полтавской. Киев : Унив. тип., 1869. 308 с.

32. Рогович А.В. Обозрение сосудистых и полусосудистых растений, входящих в состав флоры губерний Киевской, Черниговской и Полтавской. Киев : Унив. тип., 1855. 147 с.

33. Серебряков И.Г. Морфология вегетативных органов высших растений. Москва : Советская наука, 1952.391 с.

34. Сытник К.М., Андрощук А.Ф., Клоков М.В. и др. Тысячелистники. Киев : Наукова думка, 1984. 272 с.

35. Финк В. Список некоторых растений, пригодных для культуры на неудобной земле. Записки Имп. общ. с.-х. Юж. России. 1890. № 12. C. $1-17$.

36. Фіцайло Т.В. Структурно-порівняльна оцінка диференціації ценофлор Київського плато : дис. ... канд. біол. наук : спец. 03.00.05. Київ, 2000. 432 с.

37. Флора УРСР : у 12 т. / за ред. О.В. Фоміна, С.І. Бордзіловського, С.М. Лавренка, М.І. Котова та ін. Київ : видавництво АН УРСР, 1936-1965.

38. Хохряков А.П. Таксономические спектры и их роль в сравнительной флористике. Ботанический журнал. 2000. Т. 85. № 5. C. $1-11$.

39. Цвелев Н.Н. Заметки о гераниевых (Geraniaceae) флоры Восточной Европы. Нов. сист. выси. р. 1993. Т. 29. С. 95-99.

40. Червона книга України. Рослинний світ / за ред. Я.П. Дідуха. Київ : Глобалконсалтинг, 2009. 900 с. 
41. Чопик В.И. Редкие и исчезающие растения Украины: Справочник. Киев : Наукова думка, 1978. 216 с.

42. Чорна Г.А. Нові знахідки Carex hordeistichos Vill. та Carex paniculata L. (Суреraceae) в Правобережному Лісостепу України. Украйнський ботанічний журнал. 2004. Т. 61. № 1. С. 62-68.

43. Шиндер O.I. Спонтанна флора Національного ботанічного саду імені М.М. Гришка НАН України (м. Київ). Повідомлення 2. Методологічні проблеми і критерії виділення ергазіофітів в умовах інтродукційного центру. Інтродукиія рослин. 2019а. № 2. С. 3-16. DOI: 10.5281/zenodo.3240995.

44. Шиндер O.I. Спонтанна флора Національного ботанічного саду імені М.М. Гришка НАН України (м. Київ). Повідомлення 4. Адвентивні види: Ксенофіти. Інтродукиія рослин. 2019б. № 4. С. 18-33. DOI: 10.5281 /zenodo.3566608.

45. Шиндер O.I. Хорологічні особливості Clinopodium menthifolium (Lamiaceae) i Sedum borissovae (Crassulaceae) - рідкісних видів флори Правобережжя України. Рослинний світ у Червоній книзі України: впровадження Глобальної стратегії збереження рослин : Матеріали 5 конференції (25-28 червня 2018 р.). Херсон, 2018. С. 93-96.

46. Шиндер O.I., Неграш Ю.М., Глухова С.А., Дойко Н.М., Рак О.О. Адвентивні види роду Lonicera (Caprifoliaceae) у флорі Правобережної України. Наукові записки НаУКМА. Біологія $і$ екологія. 2020. Т. 3. C. 58-65. DOI: 10.18523/2617-4529.2020.3.58-65.

47. Яворська О.Г. Адвентивна фракція синантропної флори Київської міської агломерації : дис. ... канд. біол. наук : спец. 03.00.05. Київ, 2002. 252 c.

48. Lapczyński K. Rośliny $\mathrm{z}$ okolic Białejcerkwi. Pamiętnik fizyograpiczny. Warszawa, 1889. T. 9. S. 36-54.

Information about the authors: Shynder O. I.,

Candidate of Biological Sciences,

Researcher at the Department of Natural Flora M.M. Gryshko National Botanical Garden of the National Academy of Sciences of Ukraine 1, Timiryazyevska str., Kyiv, 01014, Ukraine

Doiko N. M., Candidate of Biological Sciences, Senior Researcher, Deputy Director for Research State Dendrological Park "Alexandria" of the National Academy of Sciences of Ukraine 13, Dendrological Park “Alexandria”, Bila Tserkva, Kyiv region, 09113, Ukraine 